\title{
Interaction of murine Ets-1 with GGA-binding sites establishes the ETS domain as a new DNA-binding motif
}

\author{
Julie A. Nye, Jeannine M. Petersen, Cathy V. Gunther, Matthew D. Jonsen, and Barbara J. Graves ${ }^{1}$ \\ Department of Cellular, Viral, and Molecular Biology, University of Utah School of Medicine, Salt Lake City, \\ Utah 84143 USA
}

\begin{abstract}
The proto-oncogene ets-1 is the founding member of a new family of eukaryotic transcriptional regulators. Using deletion mutants of murine ets-1 cDNA expressed in Escherichia coli, we show that the DNA-binding domain corresponds closely to the ETS domain, an 85-amino-acid region that is conserved among ets family members. To investigate the specificity of DNA binding of the ETS domain, we mapped the DNA contacts of a monomeric Ets-1 fragment by chemical protection and interference assays. DNA backbone interactions span a 20-nucleotide region and are localized on one face of the helix. Close phosphate and base contacts are restricted to 10 central nucleotides. Contacts map to the major groove in the center of the site. Flanking minor groove interactions also are predicted. To determine the sequence preference in the close contact zone, we selected a pool of high-affinity binding sites using a purified Ets-1 carboxy-terminal fragment. Our Ets-1-selected consensus, 5'-A/GCCGGAA/TGT/C-3', differs from the binding consensus for the Drosophila ETS domain protein E74A, suggesting that specificity of action of ets family members is mediated by the ETS domain. Compared to other well-characterized classes of DNA-binding proteins, Ets-1 produces a unique pattern of DNA contacts. These studies demonstrate that the ETS domain proteins bind DNA in a novel manner.
\end{abstract}

[Key Words: DNA-binding protein; ETS domain; ets-1 transcription factor]

Received March 5, 1992; revised version accepted April 13, 1992.

Transcription factors are organized into families based on conserved structural motifs that mediate DNA binding (Steitz 1990; Harrison 1991) . Members of a particular family interact with the phosphodiester backbone and the major and minor grooves of the DNA helix in a characteristic manner. Furthermore, in many cases, members of a family bind a set of similar DNA sequences (Johnson and McKnight 1989). It is expected that different family members will activate or repress a specific set of promoter and enhancer elements. To discriminate between potential targets, the sequence-specific DNAbinding sites of family members must extend beyond the common recognition sequences. There is no code for predicting from the primary sequence which amino acids might mediate specificity of binding of different family members. Thus, every sequence-specific DNA-binding protein represents a unique problem in molecular recognition.

The ets gene family is one of the newest classes of eukaryotic DNA-binding proteins. The ets-1 gene, which

'Corresponding author. contributes sequences to the transforming oncogene of the E26 avian retrovirus (Radke et al. 1982; Leprince et al. 1983), is the founding member of the family. In addition to the original group that was discovered by sequence similarity to v-ets (ets-1, ets-2, erg, and elk-1), the family includes E74 (Burtis et al. 1990), PU.1 (Klemsz et al. 1990), GABPa (LaMarco et al. 1991), Fli-1 (Ben-David et al. 1991), Elf-1 (Thompson et al. 1992), PEA3 (Xin et al. 1992), and SAP-1 (Dalton and Treisman 1992). Some members of the family have been shown to function as transcriptional activators (Bosselut et al. 1990; Klemsz et al. 1990; Wasylyk et al. 1991; Xin et al. 1992). The family is based on a conserved domain of $\sim 85$ amino acids. The discovery of the DNA-binding competence of Ets-1, E74A, and PU.1 led us with others to propose that the conserved amino acids, designated the ETS domain, function in DNA binding (Karim et al. 1990). Conservation of the domain among family members ranges between 97 and $38 \%$ identity to Ets-1. Isolated positions of complete conservation are distributed over the entire 85 amino acids, and several patches of high conservation are striking. The features of interest include a highly basic region in the carboxy-terminal half of the domain. Eight 
basic residues are conserved and four additional basic positions have substitutions of only glutamine and asparagine. The amino-terminal half of the domain contains a highly conserved, 10 -amino-acid region that is rich in leucine. Aside from the preponderance of basic residues, the primary sequence of the ETS domain shows little similarity to any well-characterized DNA-binding motifs, suggesting that the family represents a new protein structure.

All ETS domain proteins whose DNA binding has been characterized contact a 5'-GGA-3' sequence motif (Karim et al. 1990; Hipskind et al. 1991; Thompson et al. 1991, 1992; Dalton and Treisman 1992; Xin et al. 1992). Protein interactions with only 3 bp cannot mediate highaffinity DNA binding. Furthermore, if family members regulate different target genes by distinct binding properties, additional DNA contacts must be involved. This report describes our investigation of the sequence specificity of the ets family. Deletion mutagenesis was used to map the amino acids within Ets-1 that mediate highaffinity, sequence-specific interactions. Our results indicate that the DNA-binding domain of ets-1 maps closely to the ETS domain. Alkylation interference and hydroxyl radical protection assays delineate the zone of contact of the ets-1 ETS domain on the DNA helix. Both major and minor groove interactions are implicated. Finally, a selected-and-amplified-binding ( $\mathrm{SAAB}$ ) analysis specifies the preferred DNA sequences recognized by the ets-1 protein. These studies will help identify transcriptional control elements that are potential targets for the transcriptional activation function of Ets-1. Furthermore, we propose that the contacts of Ets-1 on the DNA helix illustrate the hallmarks of ETS domain interactions with DNA. We demonstrate that the pattern is unique among known binding motifs, establishing the novelty of the ETS domain family.

\section{Results \\ Mapping the DNA-binding domain within the ets-1 protein}

Full-length and amino-terminal deletion mutants of the murine ets-1 protein were expressed in bacteria with a $\mathrm{T} 7$ polymerase-dependent expression system (Studier et al. 1990) (Fig. 1A). To produce full-length protein, we obtained an ets-1 cDNA clone containing a 1300-bp open reading frame (ORF). We placed the ORF into a pET3 vector with the first ATG positioned to be the start codon. The vector expressed a protein of an apparent molecular mass of $54 \mathrm{kD}$ (Fig. 1B, lane 4). Amino-terminal sequencing confirmed the use of the expected start codon in bacteria. Antibodies specific for ets-1 also identified a $54-\mathrm{kD}$ polypeptide in mouse tissue and T-lymphocyte cell lines (data not shown). These data suggested that the first ATG of the ORF was used in both prokaryotic and eukaryotic cells. We will refer to this $54-\mathrm{kD}$ product as Ets-1. To produce amino-terminally truncated proteins, we cloned deleted versions of the ets-1 cDNA into pET3 vectors that expressed the ets-1 sequences in- frame with the sequences of $\mathrm{T} 7$ gene 10 . All truncated proteins were stably expressed in bacteria (Fig. 1B).

The DNA-binding properties of partially purified ets-1 proteins were tested in gel mobility-shift assays. Ets-1 and three truncated proteins, $\Delta$ N170, $\Delta \mathrm{N} 322$, and $\Delta \mathrm{N} 336$, formed stable complexes with DNA (Fig. 1C). The smallest deletion mutant, $\Delta \mathrm{N} 345$, did not bind DNA (data not shown). Competition experiments tested the specificity of binding. Labeled nucleoprotein complexes were competed by DNA bearing a strong Ets-1binding site (WT) but were resistant to competition by DNA bearing a mutant site (MT) (Fig. 1C). We conclude that Ets- 1 and the truncated proteins, $\Delta \mathrm{N} 170, \Delta \mathrm{N} 322$, and $\Delta \mathrm{N} 336$ form sequence-specific complexes. Furthermore, the DNA-binding domain of Ets-1 lies within the carboxy-terminal 105 amino acids and includes 80 of the 85 amino acids of the ETS domain (Fig. 1A).

In the DNA-binding assays presented in Figure 1, the amount of added extract was adjusted to present comparable binding activities from the various ets-1 polypeptides $(>90 \%$ shift of probe DNA). This strategy required larger amounts of Ets-1 and $\Delta \mathrm{N} 170$-containing extracts than of $\Delta N 322-$ and $\Delta N 336$-containing extracts. This differential binding activity could not be explained by a significant difference in the purity of soluble ets-1 polypeptides (Fig. 1B, lanes 5,7,9,11). Possibly, the extremely truncated ets-1 polypeptides bind DNA more avidly than the larger ets-1 polypeptides. Alternatively, the specific activity of the proteins could differ. We will describe attempts to distinguish these possibilities in the discussion. More importantly, for our continued analyses, these observations led us to assume that the truncated polypeptides, which displayed relatively high binding activity, were appropriate reagents for further binding studies.

\section{Ets-1 binds DNA as a monomer}

An important question concerns the oligomerization state of Ets-1 in solution and bound to DNA. We obtained highly purified preparations of Ets-1 and $\Delta$ N322 to investigate oligomerization. Gel filtration on Superose 12 with $\Delta \mathrm{N} 322$ and with Ets-1 showed elution profiles expected for monomeric species (data not shown). To investigate the oligomerization state of bound Ets-1, the truncated and full-length versions of Ets- 1 were mixed and added to DNA. An oligomeric protein-DNA complex formed by Ets-1 and $\Delta$ N322 would have intermediate mobility in a gel-shift assay compared with homotypic complexes composed solely of Ets-1 and $\Delta \mathrm{N} 322$. Complexes of intermediate mobility were not observed (Fig. 2). We repeated this experiment under conditions in which the mixed proteins were denatured in $6 \mathrm{M}$ urea and renatured before addition of DNA. Again, no apparent heterotypic complexes were observed (data not shown). Although formally we have not excluded the possibility that an oligomerization domain is missing in $\Delta N 322$, we tentatively concluded that Ets-1 binds DNA in specific complexes as a monomer. Additional data in support of this proposal will be presented below. 

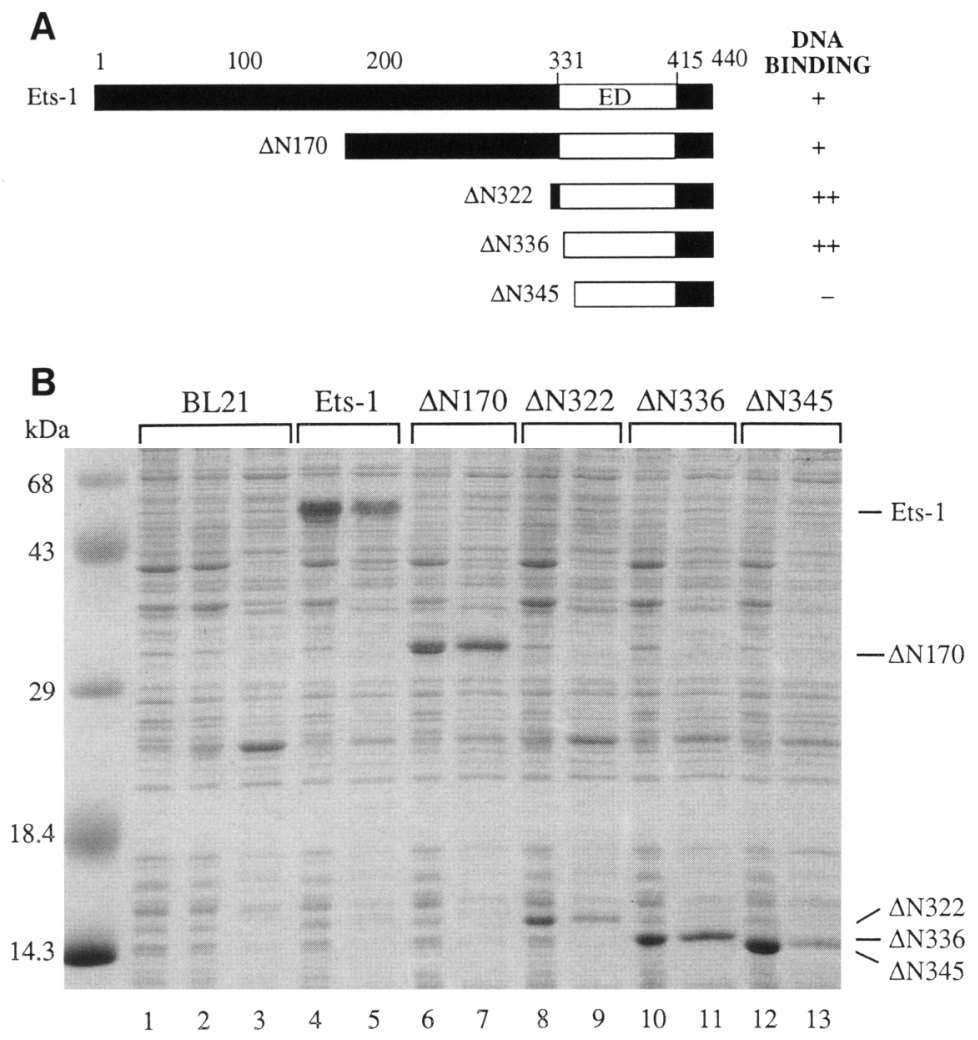
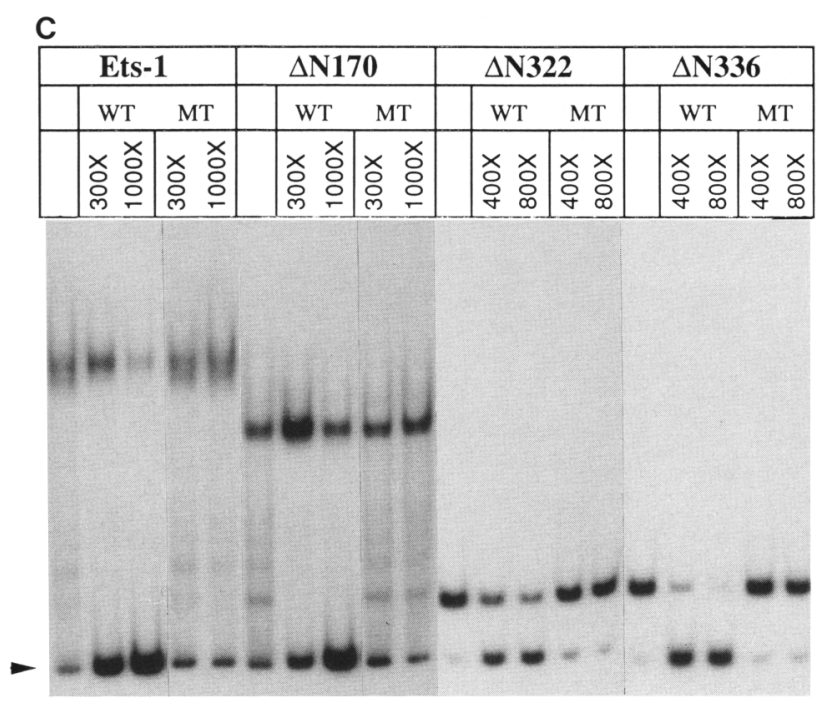

DNA protection by Ets-1

Ets-1-binding sites are present in the long terminal repeat (LTR) of the Moloney murine sarcoma virus (MSV) (Gunther et al. 1990), the polyoma enhancer (Wasylyk et al. 1991), the enhancer of the T-cell receptor- $\alpha$ subunit gene (Ho et al. 1990), and the promoter of the stromelysin gene (Wasylyk et al. 1990) (Fig. 3). The only invariant sequence is a conserved triplet, $5^{\prime}$-GGA-3'. Other ETS domain proteins also have a GGA motif in their binding sites (Fig. 3). To explore the hypothesis that de-
Figure 1. Mapping the DNA-binding domain of the ets-1 protein. $(A)$ Schematic structure of full-length and truncated Ets-1 polypeptides. ED designates the location of 85-amino-acid ETS domain. (B) Photograph of a Coomassie blue-stained SDS-polyacrylamide gel showing ets-1 gene products synthesized in bacteria. (Lane 1) Uninduced BL21 cells lysed by SDS; (lanes $2,4,6,8,10,12$ induced cells lysed by SDS; (lanes $3,5,7,9,11,13$ ) partially fractionated soluble proteins from induced cells. $(C)$ Autoradiograph of polyacrylamide gel showing mobility-shift assays of Ets-1 polypeptides binding to $\mathrm{SC} 2$ site (for description of SC sites, see Fig. 8). Fractionated extracts $(B)$ were used. The arrowhead marks the mobility of free DNA. Assays of Ets-1 and $\Delta \mathrm{N} 170$ contained $1 \mu \mathrm{g}$ of extract, $0.25 \mathrm{ng}$ of probe, and $0.5 \mu \mathrm{g}$ of poly[d(I-C)]. Assays of $\Delta \mathrm{N} 322$ and $\Delta \mathrm{N} 326$ contained $50 \mathrm{ng}$ of bacterial extract, $0.03 \mathrm{ng}$ of probe, and $0.5 \mu \mathrm{g}$ of poly[d(I-C)]. Assay of $\Delta \mathrm{N} 345$ (not shown) had $3 \mu \mathrm{g}$ of extract and $1.5 \mathrm{ng}$ of poly[d(I-C)]. A molar excess of unlabeled competitor DNA was added as indicated $(x)$. Competitor DNA was either a wild-type (WT) or mutant (MT) version of the Ets-1-binding site in the promoter of the MSV LTR (Gunther et al. 1990).

terminants of Ets-1 binding include additional sequences, we mapped the contacts made by Ets-1 on a variety of DNA-binding sites. To facilitate comparison of data from multiple sites, we numbered 20 positions within each Ets-1-binding site. The GGA triplet /designated by positions 10,11 , and 12 on the top strand in each binding site) served as the point of reference.

In a DNase I protection analysis, $\Delta \mathrm{N} 322$ protected 16 nucleotides on the GGA strand and 18 nucleotides on the TCC strand (Fig. 4A,B). In the center of the protected region, a DNase I cleavage site was observed near the 
Nye et al.

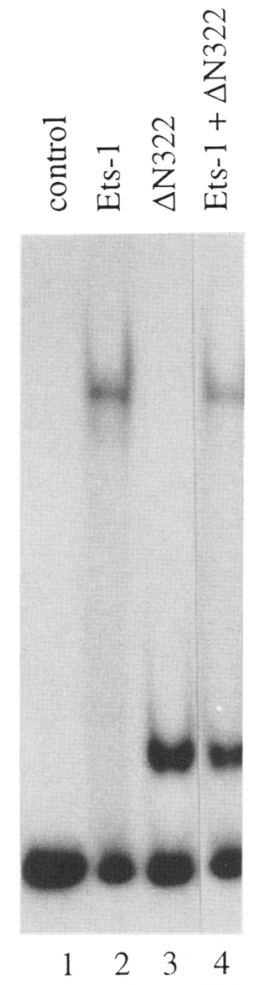

Figure 2. DNA binding by Ets-1, $\Delta \mathrm{N} 322$, and a mixture of the two proteins. The binding of highly-purified Ets- 1 and $\Delta N 322$ to the SC2 site probe was assayed in gel mobility-shift assays. In lane 4, Ets-1 and $\Delta$ N322 were mixed and allowed to incubate for $20 \mathrm{~min}$ before the addition of probe. The molar ratio of Ets-1/ $\Delta \mathrm{N} 322$ was $100: 1$ in this reaction.

conserved triplet on the TCC strand (Fig. 4B). This analysis was performed on the SC2-binding site described in Figure 8, below. This same pattern of cleavage and protection is observed in $\Delta$ N170-mediated footprints on the MSV LTR promoter site (Gunther et al. 1990). We detected a similar pattern in $\Delta \mathrm{N} 322$-mediated footprints on the enhancer of the MSV LTR and in Ets-1-mediated footprints on both the promoter and enhancer sites of the MSV LTR (data not shown). The consistency of the DNase I footprint suggests that Ets-1, $\Delta \mathrm{N} 170$, and $\triangle \mathrm{N} 322$ contact DNA in an identical manner.

We then used hydroxyl radical protection to study interactions of $\Delta \mathrm{N} 322$ with the DNA backbone. Direct protein contact or protein-induced changes in the DNA conformation can affect the susceptibility of deoxyribose within the backbone to hydroxyl radical attack (Tullius et al. 1987). In the absence of protein, hydroxyl radicals cleaved the probe DNA uniformly (Fig. 4A,B), indicating that the binding-site DNA had no unusual structure. $\Delta N 322$ protected two patches of nucleotides on each strand of the binding site. A quantitative analysis of these data demonstrated that significant protection $(>20 \%)$ on the GGA strand spanned 4- and 6-nucleotide patches, whereas the two patches on the TCC strand each included 6 nucleotides (Fig. 4C). Two slightly enhanced cleavage sites at positions 12 and 13 on the GGA strand were evident by the apparent negative protection in the histogram.

The display of the data on a helix model illustrates the juxtaposition of protected regions between positions 15 and 20 on the GGA strand across the minor groove from the backbone protection at positions 12-17 on the TCC strand (Fig. 4D). Likewise the region of protection between 6 and 9 was positioned across the minor groove from the protection between positions 3-6. The regions of protection flanked the conserved GGA triplet and mapped to one face of the DNA helix. A protein structure interacting with DNA over 20 nucleotides predominantly on one face of the helix could account for this pattern of hydroxyl radical footprinting. An altered DNA conformation that might accompany protein binding also could explain some of the protection data.

\section{Interference of Ets-1 binding by phosphate ethylation}

We performed ethylation interference experiments to assay more directly for protein contacts on the DNA phosphodiester backbone. Ethylation of DNA at phosphates by $N$-ethyl $N$-nitrosourea (ENU) (Siebenlist and Gilbert 1980) can interfere sterically with protein-DNA contacts or interfere by disrupting potential electrostatic interactions. In these experiments, probe DNA was ethylated and challenged with ets-1 polypeptides. The ethylation of two phosphates on the GGA strand and four phosphates on the TCC strand interfered significantly (greater than fivefold effect) with Ets-1 binding (Fig. $5 \mathrm{~A}, \mathrm{~B})$. The positions of the most severe interference flanked the GGA triplet. The helix model (Fig. 5C) illustrates that the sites of the strongest interference lie near the major groove in the center of the binding site. Figure $5 \mathrm{~B}$ compares ethylation interference data from Ets-1 and $\Delta N 322$ experiments. The positions and ranking of interference were almost identical in the two analyses. These results support our assumption that the carboxy-terminal fragment of Ets-1 and full-length Ets-1 make similar DNA contacts.

\section{Interference of Ets-1 binding by purine methylation}

We used methylation interference to probe Ets-1 interactions within the helix grooves. Dimethyl sulfate methylates guanine residues at the $N_{7}$ position in the major groove and adenine residues predominantly at the $\mathrm{N}_{3}$ position in the minor groove. We studied two different Ets-1-binding sites because this analysis probed only G and $A$ residues. We classified sites of interference as either strongly interfering (5- to 10-fold effects) or mildly interfering (1.5- to 3-fold effects). In each binding site, methylation of the two G residues within the GGA triplet strongly interfered with binding (Fig. 6A,B). The only other interference in the severe category was at position 8 on the GGA strand of the promoter-binding site (Fig. 6B). The strong guanine methylation interference suggests close DNA contacts within the major groove between positions 8 and 11 . Sites of less severe interference mapped to every $G$ residue within positions 8 and 16 on 


\begin{tabular}{lll}
\hline Ets-1 & & \\
MSV LTR enhancer & ACAGGATATC & (this report) \\
MSV LTR promoter & AGCGGAAGCG & Gunther et al. (1990) \\
Polyoma enhancer & CGAGGAAGTG & Wasylyk et al. (1990) \\
T-Cell Receptor $\alpha$ & AGAGGATGTG & Ho et al. (1990) \\
Stromelysin & GCAGGAAGCA & Wasylyk et al. (1991) \\
& CCAGGAAATG & \\
\hline E74A & & Urness and Thummel (1990) \\
E74A & CCCGGAAGTA & \\
PU.1 & & Klemsz et al. (1990) \\
MHCII & AGAGGAACTT & \\
GABP $\alpha$ & & Thompson et al. (1991) \\
HSV ICP4 & AACGGAAGCG & \\
& AGCGGAAACC & \\
SAP-1 & & Dalton and Treisman (1992) \\
Elk-1 & & Hipskind et al. (1991) \\
c-Fos & ACAGGATGTC & \\
\hline
\end{tabular}

the two binding sites and to position 4 on the promoterbinding site. The significance of these sites will be considered in the Discussion. Adenine methylation interference was assayed only on the A-rich site (Fig. 6A). The most severe interference (6- to 10-fold effects) was observed at positions 13 and 15 on the TCC strand. The strong adenine interference suggests close contact by protein in the minor groove between positions 13 and 15 . Less severe interference (2- to 3-fold effects) accompanied methylation at positions 7,12 , and 14 on the GGA strand. The sites of guanine and adenine methylation interference between positions 7 and 16, as well as the absence of interference at flanking positions (positions numbered 6 and below, plus positions numbered 17 and above), indicate that close contact of Ets-1 with the surface of the helix grooves is restricted to $10 \mathrm{bp}$.

\section{Selected and amplified binding sites: an Ets-1 consensus site}

The protection and interference data demonstrated that backbone interactions spanned a 20-nucleotide region, whereas close phosphate and base contacts mapped to only 10 contiguous nucleotide pairs. We predicted that the most important sequence determinants for Ets-1 DNA binding would lie within the more restricted close contact region. To elucidate the sequence preferences at these positions, we employed a binding-site selection technique (Blackwell and Weintraub 1990). In brief, we generated a pool of DNA molecules (52 bp in length) with a central GGA flanked by seven randomly specified positions, $5^{\prime} \ldots$ NNNGGANNNN . . . 3'. High-affinity binding sites for $\triangle N 322$ were selected from the pool by gel mobility-shift assays. Selected DNA molecules were subjected to polymerase chain reaction (PCR) amplification with primers that flanked the central $20 \mathrm{bp}$. The amplified DNA was sequenced by dideoxy sequencing using radiolabeled primers. In addition, the amplified DNA was radiolabeled and used in the next selection
Figure 3. DNA-binding sites for ETS domain proteins. Sites have been aligned by the invariant GGA triplet (underline). In all cases, mutational analyses or methylation interference have shown that the GGA nucleotides are involved in DNA binding.

assay. The selection and amplification procedure was repeated five times. An additional round of selection was performed under more stringent binding conditions, yet no decrease in the complexity of the consensus was observed.

The random composition of the positions flanking the invariant GGA (bp 7-9; bp 13-15) is shown in the sequence of the starting pool (start, Fig. 7). A set of nonrandom sequences, a "selected consensus", was obtained after five rounds of selection (Figs. 7 and 8). Sequencing of both strands showed similar preferred sequences. Parallel selection on a separate, identical pool of DNA molecules also derived the same set of preferred sequences (data not shown). The selection experiments detected preferences at only six of the seven positions assayed. In addition, the study indicated that five of these positions exhibited dual preferences. To determine whether the dual preferences represented as many as 32 different sites or only a subset of this maximal number, we cloned and sequenced 15 randomly selected molecules of the round 5 pool. The sequences of the selected and cloned sites (SC sites) are presented in Figure 8. Sequences in lowercase do not match the most frequently selected nucleotide in the consensus. Boxed positions in each site fail to match the consensus. The frequency of nucleotides in only these 15 clones (Fig. 8) was sufficient to suggest a consensus that is similar to the selected consensus. In addition, these individual clones confirmed that the selected pool of sites contains considerable diversity. Only two pairs of sites showed the identical sequence at all six selected positions.

To understand the significance of the degenerate consensus, we determined the relative affinity of the SC sites. By quantitative gel mobility-shift assays, the equilibrium dissociation constant of $\Delta \mathrm{N} 322$ for the SC2 site was calculated to be $4.9 \times 10^{-11}$ (for details of this determination, see Materials and methods). The apparent affinities of the other 14 clones were determined by competition titrations (Lui-Johnson et al. 1986; Li et al. 
A

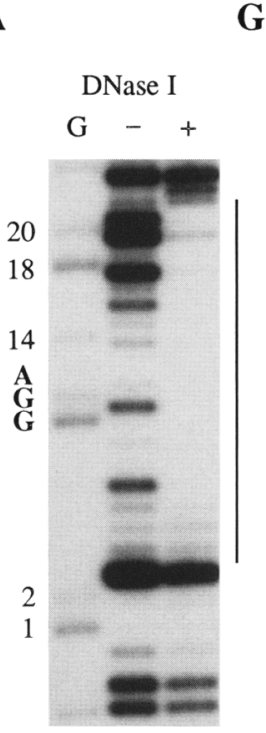

GGA

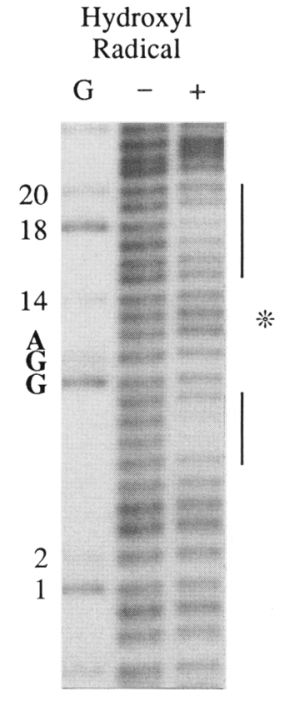

C

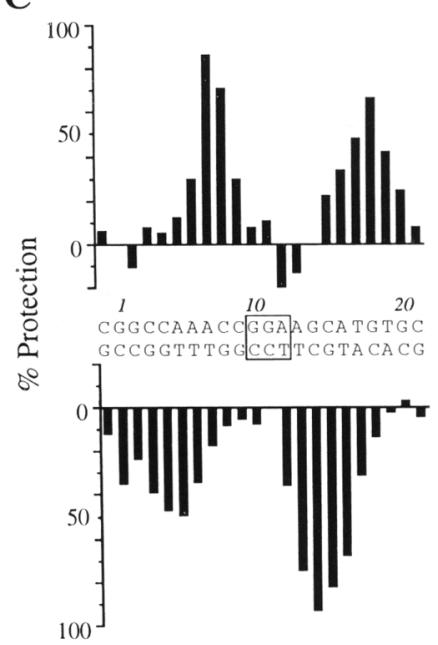

TCC

B

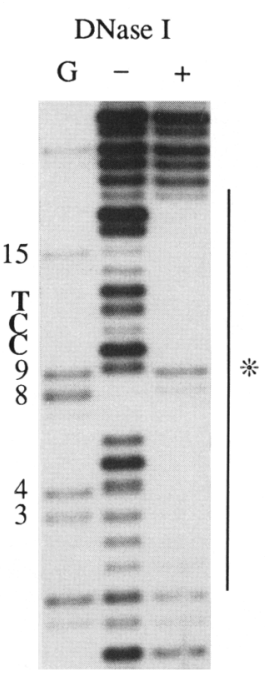

D

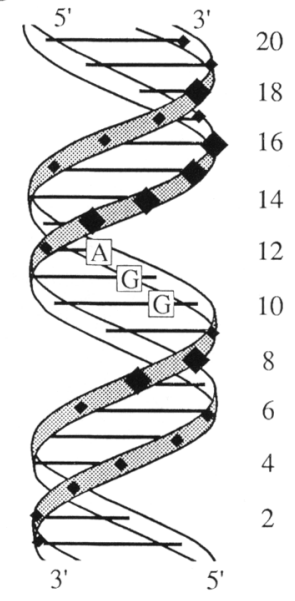

Figure 4. DNase I and hydroxyl radical protection assays. $(A, B) \mathrm{Au}$ toradiograph of a denaturing polyacrylamide gel showing protection of the SC2 site sequences (for description of SC sites, see Fig. 8). DNA was exposed to cleavage reagents in the absence (- lanes) or presence (+ lanes) of $\Delta \mathrm{N} 322$. Lanes $G$ contain the products of chemical sequencing reactions for $G$ residues that serve as sequence markers. Binding site coordinates are presented for these marker positions. Vertical bars indicate regions of protection. Asterisks $\left({ }^{*}\right)$ denote positions of hypersensitivity to cleavage reagents. $(C)$ Hydroxyl radical protection is plotted as a function of sequence positions of both strands of the SC2-binding site. Protection was calculated from relative autoradiographic densities according to the equation \% protection $=(1-[$ Absorbance $(+$ lane $) /$ Absorbance $\mid-$ lane $)] \times 100 \%$. Positions outside of the binding site showed $<10 \%$ variation from the origin. $(D)$ B-form DNA helix showing positions of hydroxyl radical protection. Sites of $20-50 \%$ protection are marked by small diamonds; sites showing $>50 \%$ protection are marked by large diamonds.

1989). The clones (SC1-SC15) are ranked according to their relative affinities and organized into four groups in Figure 8 . The affinities of the binding sites varied over two orders of magnitude. These quantitative studies demonstrate that the relative match to the selected consensus correlates with the relative affinity of a particular site. Thus, the selected consensus will be useful in predicting the strength of other Ets-1-binding sites. This collection of sites also should predict the location of possible Ets-l binding sites in viral and cellular enhancers. Interestingly, previously reported Ets-1 binding sites (Fig. 3) do not match the SC clones with the highest affinities, suggesting that biological regulatory mechanisms utilize sites with less than optimal binding affinities.

The selected consensus and the strongest binding sites included a minimal twofold symmetry, 5'-CCGG-3'. Sites SC9 and SC12 contained the larger palindromic sequence $5^{\prime}$-TCCGGA-3', but these clones did not show the highest affinities. Binding sites for proteins that bind as homodimers often have relative affinities that are proportional to the degree of symmetry of the binding-site sequence. Thus, the selection experiment supports the proposal that a single Ets-1 polypeptide recognizes a single GGA motif.

Two groups have recently reported a selected consensus for Ets-1: A/GG/CC/aGGAAGT/c (Fisher et al. 1991); ACC/AGGAA/TA/G (Woods et al. 1992). These complementary studies strengthen our conclusions. Although no quantitative analysis of individual clones was presented in these studies, the selected binding sites display sequences that would position them high in our affinity hierarchy (Fig. 8). Both studies used full-length Ets-1 (either expressed in SF9 cells or prepared from T-cell nuclear extracts), thus supporting our assumption that the DNA binding of $\Delta \mathrm{N} 322$ expressed in bacteria accurately represents Ets-1 activity. In each study, the number of randomly specified positions in the starting 
A

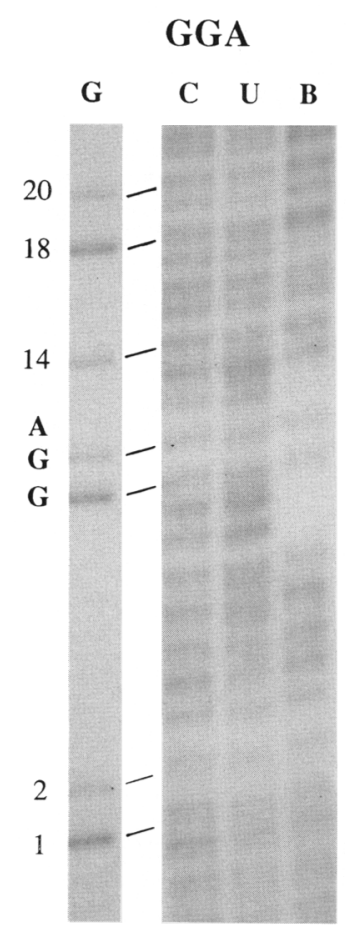

B

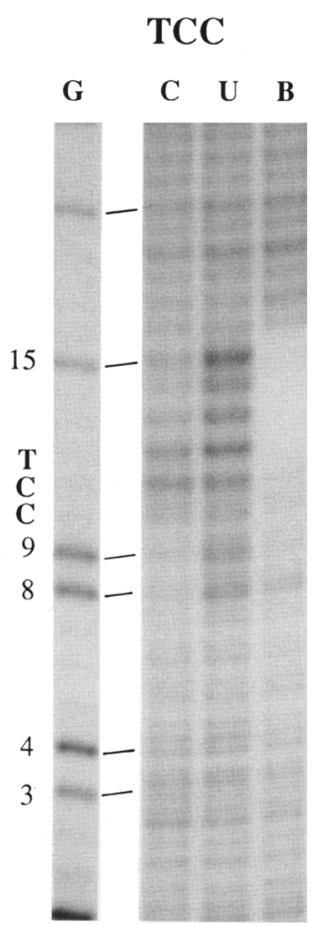

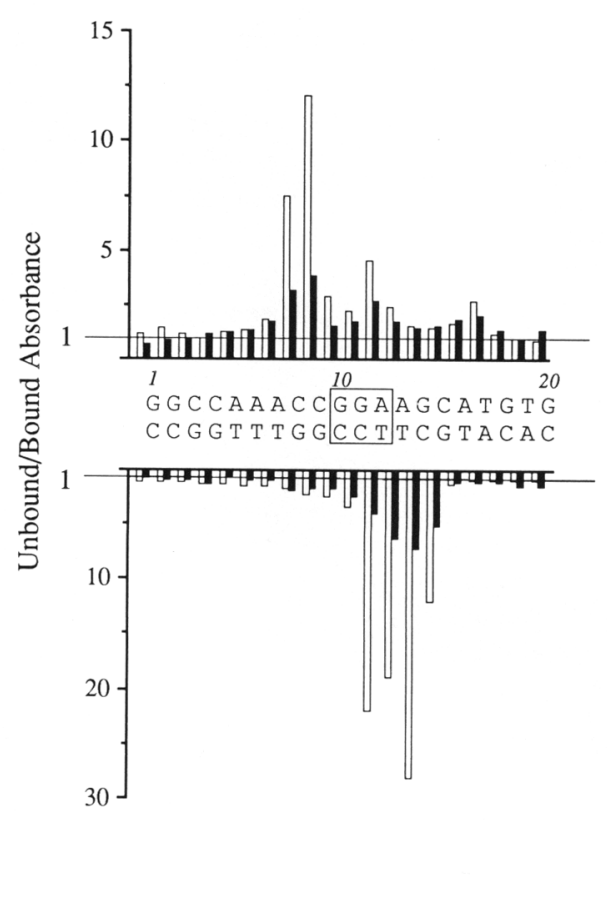

C

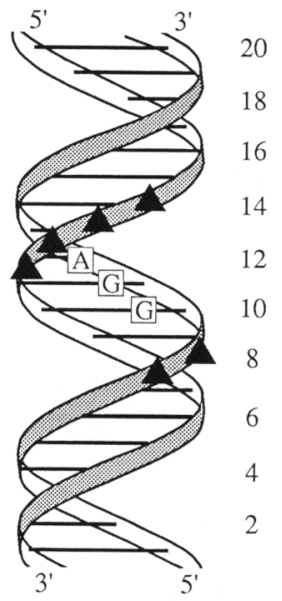

Figure 5. Ethylation interference analysis of Ets-1 binding. (A) Autoradiograph of analysis performed with the 54-kD ets-1 protein on the SC2 site. DNA fragments were labeled and ethylated, to a limited degree, with ENU and incubated with protein. Bound and unbound DNA fractions separated on a nondenaturing gel were cleaved with alkali. Positions of cleavage were mapped by electrophoresis on a denaturing gel (shown). The alkali cleavage of phosphotriester bonds generates fragments terminating in either a hydroxyl group or an ethylated phosphate. These fragments display slightly different mobility (visible as doublets in the lower portion of the gel); the fragment with the ethylated phosphate migrates more slowly than the other cleavage product. Lanes $G$ contain the products of chemical sequencing reactions for $\mathrm{G}$ residues that serve as markers. The markers migrate slightly faster than both of the alkali cleavage products. $C$ designates lanes loaded with DNA that was modified and cleaved in the absence of protein. Lanes $U$ show the cleavage products of unbound DNA; lanes $B$ represent the assay of bound DNA. $(B)$ Quantitative analysis of the degree of sensitivity to ethylation, Ets-1 (open bars) and $\Delta \mathrm{N} 322$ (solid bars). The relative autoradiographic density of lanes loaded with unbound and bound DNA is plotted as a function of sequence position for both strands (note difference in scale). Bars are positioned to designate 5 '-ethylated phosphate of a numbered base pair. Phosphates at which ethylation had no effect on binding have a unity value. $(C) B$-form DNA helix, with triangles marking the sites of ethylation interference that show greater than a fivefold effect.

pool was greater than the seven positions assayed in our study. Nevertheless, preferred sequences were restricted to the same positions observed in our study (positions 7-15). Thus, binding-site analyses indicate that Ets-1 recognizes specific DNA sequences over only a 9-bp region.

\section{Discussion}

\section{Protein determinants for Ets-1 DNA binding}

The deletion mutagenesis demonstrated that the DNAbinding domain of Ets-1 includes the conserved 85amino-acid ETS domain. The smallest mutant that bound DNA, $\triangle N 336$, retained 80 amino acids of the ETS domain plus 25 carboxy-terminal residues. Parallel studies performed by Lim and colleagues (1992) on chicken Ets-1 are consistent with these conclusions. An Ets-1 polypeptide containing only the 85 amino acids of the ETS domain also binds DNA with high affinity (J.M. Pe- tersen, unpubl.). Domain mapping studies of other ets family members have led to similar findings. A polypeptide containing the ETS domain of GABP $\alpha$ plus 3 amino acids on the amino terminus and 7 amino acids on the carboxyl terminus mediates DNA binding (Thompson et al. 1991). Likewise, truncated PEA3 that retains the ETS domain plus 18 amino acids on the carboxyl terminus binds DNA (Xin et al. 1992).

Two independent approaches indicated that the ETS domain of a single ets-1 polypeptide recognizes a single GGA motif. In mixing experiments, no heterotypic complexes of truncated and full-length ets-1 polypeptides bound DNA. In the consensus selection, the relative affinities of binding sites did not correlate with the degree of symmetry of the DNA sequence. Association of one ETS domain with a single GGA motif is also proposed for DNA binding by GABP (Thompson et al. 1991). In this case, high-affinity DNA binding is mediated by two identical $\alpha$-subunits that each contain an ETS domain. 
Figure 6. Methylation interference analysis of Ets-1 binding. Autoradiograph of analyses performed on the MSV LTR enhancer site $\langle A|$ and promoter site $(B)$ with Ets-1 and $\triangle N 170$, respectively. The analysis of the GGA strand in $B$ was reported previously (Gunther et al. 1990). The G and A residues were modified with dimethyl sulfate, and the interference analysis was performed as described in Fig. 5. Lanes $C, U$, and $B$ show control, unbound, and bound DNA, respectively. The degree of sensitivity to methylation was determined from the relative autoradiographic density of lanes loaded with unbound and bound DNA. Circles and squares indicate tested $\mathrm{G}$ and $\mathrm{A}$ residues, respectively. Solid symbols mark sites with 5 - to 10 -fold differences in densities; shaded symbols are positions at which methylation showed 1.5- to 3 -fold effects. Open circles and squares are positions at which methylation had no effect on protein binding.
A

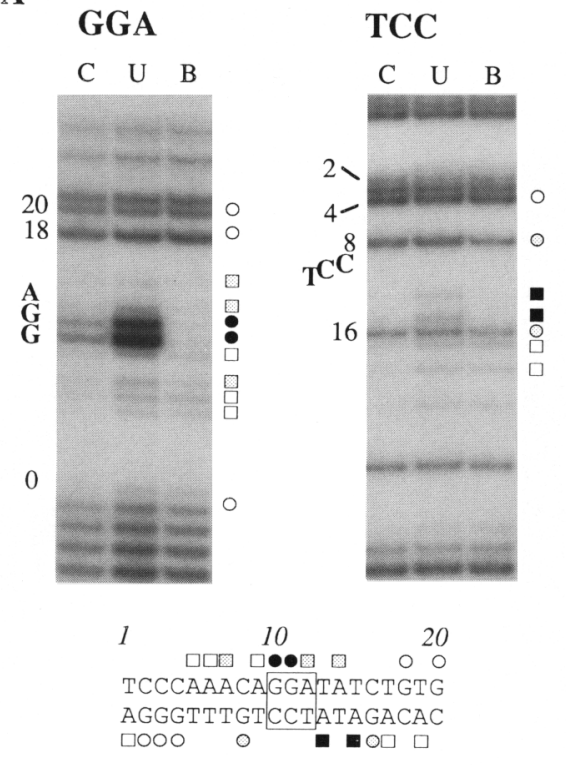

B

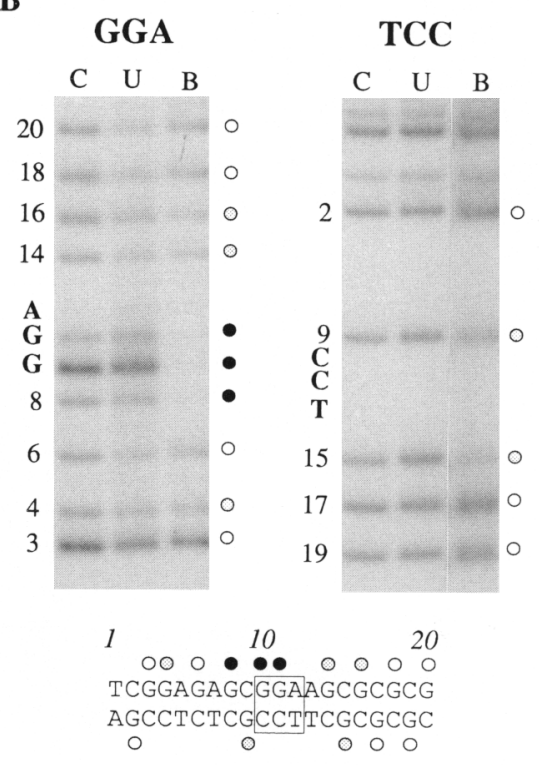

Each $\alpha$-subunit is modeled to contact a single GGA motif.

These protein studies suggested that truncated ets-1 polypeptides were suitable reagents for mapping the DNA contacts of Ets-1. Consistent with this proposal, Ets- 1 and $\Delta N 322$ showed identical DNA contacts in both DNase I protection and ethylation interference experiments. However, we observed that the protein preparations of the truncated ets-1 polypeptides display greater
DNA-binding activity than protein preparations containing equivalent amounts of full-length Ets-1. For example, a 100-fold molar excess of Ets- 1 over $\Delta$ N322 was necessary to shift approximately equal amounts of probe in binding assays of highly purified protein preparations (Fig. 2). Ets-1 could have a weaker affinity for DNA than the $\Delta \mathrm{N} 322$ species. Alternatively, a significant fraction of Ets-1 could be inactive in DNA binding.

Our preliminary investigation of this phenomenon has
Figure 7. Nucleotide sequence of the pool of selected and amplified binding sites. Autoradiograph of DNA sequencing gel showing sequence of template DNA before (Start) and after (Round 5) selection. Double-stranded DNA with seven random positions flanking an invariant central triplet 5'-GGA-3' was obtained by chemical synthesis of the TCC strand followed by enzymatic synthesis of the GGA strand (for additional details, see Materials and methods). (N) The presence of all four nucleotides with even frequency at positions 13-16 and 7-9. The starting DNA was incubated with $\triangle \mathrm{N} 322$ and electrophoresed on a nondenaturing gel to select molecules that contained high-affinity binding sites for $\triangle N 322$. DNA molecules in the bound pool were recovered from the gel and amplified by PCR. Five rounds of selection and amplification were performed. The se-
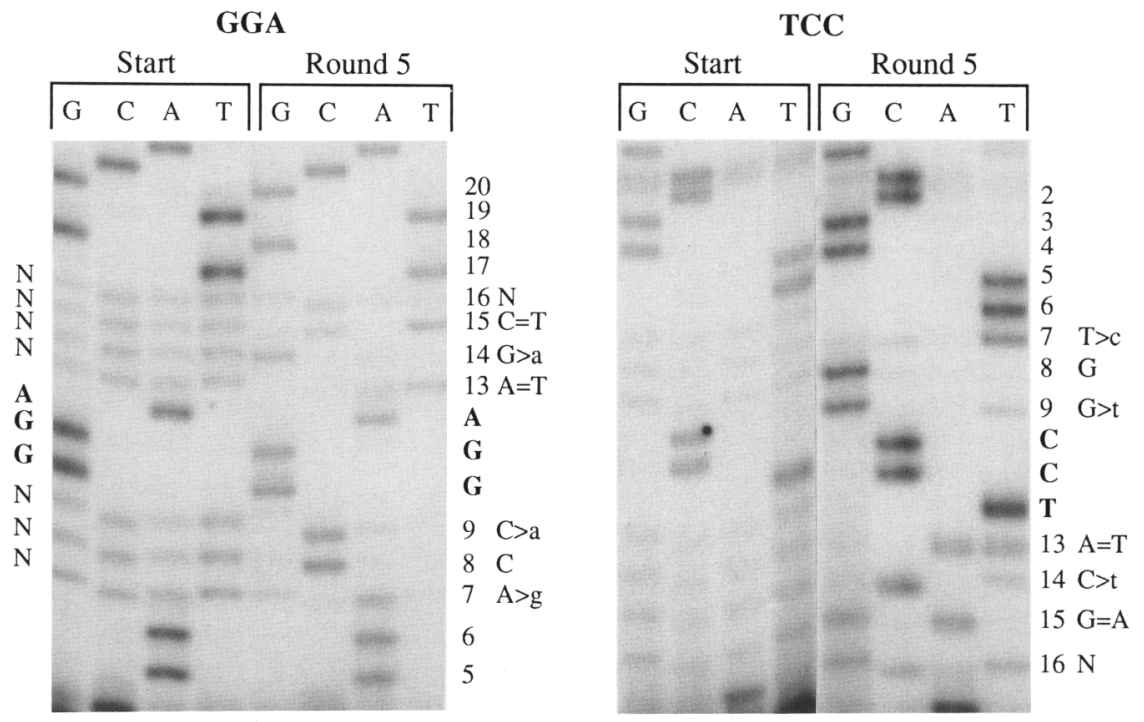

quence presented to the right of each panel is termed the selected consensus. Nucleotides in uppercase are the primary selection that was observed with a frequency of $\geqslant 0.5$. Sequences in lowercase represent nucleotides with a frequency of $<0.5$ but $>0.1$, which we termed the secondary selection. At position 15, the sequence data from the two strands differed. We chose the sequence of the TCC strand for the consensus because additional data in Fig. 8 support this choice. 


\begin{tabular}{|c|c|c|c|c|c|c|c|c|c|c|c|c|}
\hline \multicolumn{2}{|c|}{$\begin{array}{c}\text { Selected } \\
\text { Consensus }\end{array}$} & $\begin{array}{l}\text { A } \\
\text { g }\end{array}$ & c & $\begin{array}{l}\text { C } \\
\text { a }\end{array}$ & G & G & A & $\begin{array}{l}A \\
T\end{array}$ & $\begin{array}{l}G \\
a\end{array}$ & $\begin{array}{l}\mathrm{C} \\
\mathrm{T}\end{array}$ & & \\
\hline \multicolumn{12}{|c|}{ SElectfed Clones } & $\mathrm{K}_{\mathrm{d}} \times 10^{-11} \pm$ S.D \\
\hline \multirow{5}{*}{ I } & SC1 & $\mathrm{g}$ & C & C & $\bar{G}$ & G & $A$ & A & G & $\mathrm{T}$ & G & $3.8 \pm 0.10$ \\
\hline & SC2 & A. & c & c & G & G & A & A & $\mathrm{G}$ & C & A & 4.9 \\
\hline & SC3 & g & c & c & G & G & A & $T$ & G & $\mathrm{T}$ & A & $4.9 \pm 0.25$ \\
\hline & SC4 & A & C & c & G & G & A & A & G & $\mathrm{C}$ & $\mathrm{T}$ & $5.7 \pm 0.57$ \\
\hline & $\mathrm{SC5}$ & A & $\mathrm{C}$ & c & G & G & $\mathrm{A}$ & $\mathrm{T}$ & $a$ & $\mathrm{~T}$ & A & $7.6 \pm 0.36$ \\
\hline \multirow{6}{*}{ II } & SC6 & C & c & C & G & G & $\mathrm{A}$ & A & G & $\mathrm{T}$ & G & $12 \pm 0.32$ \\
\hline & $S C 7$ & A & c & a & $G$ & $\mathrm{G}$ & A & $A$ & G & $\mathrm{T}$ & c & $12+0.00$ \\
\hline & SC8 & g & C & c & G & G & A & $\mathrm{T}$ & G & c & A & $12 \pm 0.85$ \\
\hline & $5 C 9$ & $t$ & $c$ & C & G & G & $A$ & A & $\mathrm{G}$ & $\mathrm{T}^{\mathrm{T}}$ & A & $24 \pm 0.62$ \\
\hline & sc10 & $\vec{A}$ & $c$ & $a$ & G & G & $A$ & A & $\mathrm{G}$ & $\mathrm{C}$ & G & $14 \pm 0.60$ \\
\hline & sc11 & A & c & a & G & $G$ & $A$ & $\mathrm{~T}$ & $a$ & $\mathrm{~T}$ & G & $16 \pm 1.4$ \\
\hline \multirow{2}{*}{ III } & $\mathrm{SC} 12$ & $t$ & c & c & G & G & A & A & a & $c$ & C & $29 \pm 2.2$ \\
\hline & SC13 & A & $\mathrm{C}$ & $a$ & G & G & A & $\mathrm{T}$ & a & $\mathrm{T}$ & c & $33 \pm 1.2$ \\
\hline \multirow{2}{*}{ IV } & $\mathrm{SC} 14$ & c & $a$ & $a$ & G & G & $\lambda$ & C & $G$ & $a$ & $c$ & $240 \pm 60$ \\
\hline & SC15 & $t$ & & $\mathrm{t}$ & $G$ & G & $\mathrm{A}$ & $\mathrm{C}$ & c & $\mathrm{c}$ & $\mathrm{T}$ & $>300$ \\
\hline \multicolumn{2}{|c|}{$\begin{array}{l}\text { NUCLIJOIIDE } \\
\text { FREQUENCIES } \\
\text { SCl-SC15 }\end{array}$} & $\begin{array}{l}\mathrm{A}^{7} \\
\mathrm{G}^{3} \\
\mathrm{~T}^{3} \\
\mathrm{C}^{2}\end{array}$ & & $\begin{array}{r}{ }^{4} C^{9} \\
\mathrm{~A}^{5} \\
\mathrm{~T}^{!}\end{array}$ & & G & A & $\begin{array}{l}A \\
T \\
C\end{array}$ & $\begin{array}{ll}8 & G^{1} \\
5 & A^{4} \\
2 & C^{1}\end{array}$ & $\begin{array}{l}{ }^{10} \mathrm{~T}^{8} \\
\mathrm{~T}^{8} \\
\mathrm{C}^{6} \\
\mathrm{~A}^{1}\end{array}$ & $\begin{array}{l}A^{5} \\
G^{4} \\
C^{4} \\
T^{2}\end{array}$ & \\
\hline
\end{tabular}

Figure 8. Nucleotide sequence of the selected and amplified binding sites. The top panel presents the selected consensus obtained from sequencing the pool of selected and amplified sites (Fig. 7). Upper- and lowercase designations correspond to the relative frequency of each nucleotide in the selected consensus. Boxed sequences deviate from the selected consensus. $K_{\mathrm{d}}$ values are presented as a mean and standard deviation $(n=3)$. The affinity of SC2 was determined by DNA titrations and Scatchard analysis and the affinities of the other 14 clones were measured by competition titrations, as described in Materials and methods.

led us to consider another explanation. The DNA-binding activity of preparations of highly purified Ets- 1 is increased significantly by partial proteolytic digestion. Amino-terminal sequencing of proteolytic fragments indicates that the higher DNA-binding activity is mediated by $12-$ to $14-\mathrm{kD}$ polypeptides that contain the ETS domain (M. Jonsen and B. Graves, unpubl.). The DNA binding of chicken Ets-1 also can be activated by either deletion mutagenesis or partial proteolysis (Lim et al. 1992). In these studies, chicken Ets-1 was synthesized in reticulocyte lysates; thus, the relatively low binding activity of Ets-1 is not restricted to protein produced in bacteria. These additional studies indicate that Ets-1 contains a well-folded DNA-binding domain and suggest that the remainder of the protein is also properly folded. To explain the difference in activity of the preparations of full-length and truncated proteins, we speculate, as proposed by Lim and colleagues (1992), that the aminoterminal portion of Ets-1 negatively regulates the DNAbinding activity of the carboxy-terminal ETS domain. Interactions with other proteins might alleviate this in- hibition in vivo, increasing the DNA-binding activity of full-length Ets-1 to the level observed for $\Delta N 322$. In this model, consistent with our findings, active Ets-1 would make the same DNA contacts as truncated ets-1 polypeptides. The DNA binding of four other ETS domain proteins has been shown to be enhanced by the association with other unrelated proteins. The most active binding species of GABP contains two $\beta$-subunits in addition to the ETS domain bearing $\alpha$-subunits. PU.1 recruits an additional factor into a binding complex on the immunoglobulin $\kappa$ enhancer (Pongubala et al. 1992). Finally, both Elk-1 and SAP-1 have been shown to bind DNA in association with the serum response factor (SRF) (Hipskind et al. 1991; Dalton and Treisman 1992). We are searching for functionally analogous components that could modulate the putative inhibitory domain of Ets-1 in eukaryotic cells.

\section{DNA determinants for Ets-1 binding}

Protection and interference data are summarized schematically on a planar representation of a DNA helix in Figure 9. Data from all analyses have been aligned by the conserved GGA triplet. The hydroxyl radical protection analysis (data shown in heavy lines) showed that $20 \mathrm{nu}$ cleotides were affected by Ets-1 binding. Four clusters of sugar residues were protected from attack. The ethylation interference experiments /sites of interference marked by triangles) confirmed backbone contacts within a central 8-bp region. All possible backbone interactions mapped to one face of the helix. (We designated this surface of the helix the front face.) Methylation interference experiments (sites of interference marked by circles and squares) identified putative contacts within 10 contiguous bp (positions 7-16). The sites of strongest interference caused by base methylation also mapped to the front face of the helix. As discussed below, the configuration of chemical contacts, as well as the selected sequence preferences, suggest that Ets-1 contacts nucleotides in the major groove. Furthermore, on each side of the major groove zone, there are interactions near the minor groove.

Major groove contact zone Three types of data predicted that positions 8-12 are contacted in the major groove. (1) The strong sites of ethylation interference and hydroxyl radical protection flanked the major groove of the DNA helix that centers over position 10; (2) putative base contacts in the major groove were suggested by the strong guanine methylation interference at positions 8 , 10 , and 11 ; and $(3)$ the SAAB experiment demonstrated sequence determinants at positions 8 and 9 by selecting an invariant $C$ for position 8 and showing a strong preference for a $\mathrm{C}$ at position 9. Furthermore, six SC sites showing the strongest Ets-1 binding had a $\mathrm{CpC}$ dinucleotide at positions 8 and 9 . A C preference at positions 8 and 9 is also indicated by mutagenesis of the Ets-1 binding site in the stromelysin promoter (Wasylyk et al. 1991). The absolute conservation of the GGA at positions 10,11 , and 12 , as well as the sensitivity of these 


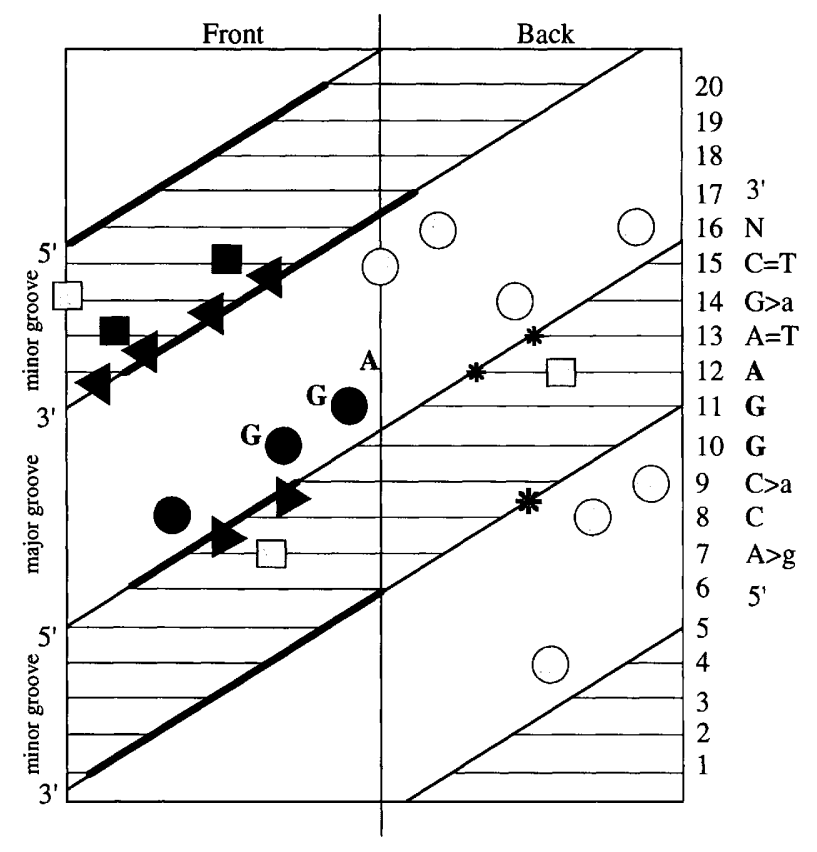

Figure 9. Summary of protection and interference data. The DNA helix is diagramed in a planar projection /Siebenlist and Gilbert 1980) (B-form helix with radius: $8.9 \AA$; helical pitch: $10.5 \mathrm{bp} /$ turn). The DNA phosphodiester backbone is represented by diagonal lines rising $3.26 \AA / \mathrm{bp}$. The base pairs are represented as horizontal lines across the minor groove (basepairing in the major groove is not pictured). The front and back designations were chosen with respect to the Ets-1 mode of binding. The coordinate system, which assigned the GGA triplet positions 10-12, allows data from multiple sites (Figs. 4-8) to be presented. Bold lines on the phosphate-sugar backbone indicate sites of hydroxyl radical protection of deoxyribose. Triangles mark the sites of ethylation interference (greater than a fivefold effect). The small asterisks mark positions of enhanced hydroxyl radical cleavage; the large asterisk marks the position of enhanced DNase I cleavage. Solid circles are sites of guanine methylation interference (5- to 10-fold effect); shaded circles are sites of modest methylation interference (1.5- to 2-fold effect). Solid squares are sites of adenine methylation interference (6- to 10-fold effect); shaded squares mark sites of modest methylation interference (2- to 3 -fold effect).

sites to mutation, is well established (Gunther et al. 1990; Ho et al. 1990; Wasylyk et al. 1990, 1991). Major groove contacts are predicted to be the most important in sequence-specific recognition because there are a variety of diverse hydrogen bond donor and acceptor sites on the bases in the major groove (Seeman et al. 1976; Harrison 1991). Thus, the strong sequence preferences suggest contacts in the major groove. In sum, data from both biochemical and genetic approaches implicate positions $8-12$ in major groove interactions.

Guanines whose methylation interfered with Ets-1 binding also mapped to positions 14,15 , and 16 . These guanine methylations displayed minor effects (1.5- to 1.9-fold) and positioned methyl groups in the major groove on the back face of the helix. Arms of Ets-1 may lie in the major groove on the back face of the helix, making few specific base contacts and no phosphodiester backbone contacts. Alternatively, this modest interference on the back face of the helix may be the result of less direct effects of methylation. For example, methylation can alter the charge distribution on the purine ring structure, an effect that would show no groove specificity. Methylation interference has also been shown to affect protein binding by indirect effects on DNA conformation (McClarin et al. 1986).

Minor groove interactions The hydroxyl radical protection flanked the proposed major groove contact zone and extended over the minor groove on the front face of the helix. This protection could accompany protein interactions with base pairs within the minor groove or protein contacts that are positioned only on the backbone. To attempt to distinguish these alternatives, we must consider the nature of the sequence determinants in this region. In selection experiments, dual preferences were selected at positions 13-15, whereas no preference was detected at position 16. Position 7 was also identified as a degenerate sequence determinant. The importance of sequence composition in these regions is also suggested by the mutational analysis of the stromelysin promoter (Wasylyk et al. 1991), although the consensus degeneracy in these regions was not anticipated by the mutational analysis. On one hand, DNA-binding specificity could be mediated by base pair contacts in the minor groove in which there is minimal distinction between base pairs (Seeman et al. 1976). For example, either a $\mathrm{C}: \mathrm{G}$ or a $\mathrm{T}: \mathrm{A}$ base pair at position 15 could participate in a hydrogen bond with Ets- 1 via the oxygen of the pyrimidine ring. Methylation interference analysis also suggested base contacts in the minor groove at position 7 and positions 13-15. Alternatively, the nonstringent sequence requirements may reflect a selection for a sequence that favors a DNA conformational change. In this context, we note the conservation of a purine-pyrimidine step at positions 14-15 on the GGA strand in the high-affinity SC sites, a feature noted for its effect on DNA conformation (Calladine 1982). In conclusion, base contacts with limited sequence specificity and sequencedependent DNA conformation changes may both contribute to the interactions in the minor groove contact zone.

Several observations indicated that DNA conformational change is a feature of Ets-1-binding specificity. The bound DNA, for example, was sensitive to cleavage by hydroxyl radical and DNase I on the back face of the helix. Accessibility or reactivity to cutting reagents may be enhanced by an altered conformation of the minor groove between positions 8 and 13. An interesting feature of the chemical mapping data was the protection from hydroxyl radical that extended $5 \mathrm{bp}$ in each direction beyond the region containing close base and phosphate contacts. This hydroxyl radical protection could be the result of protein binding in the central major groove zone and indirectly narrowing the flanking minor grooves. We have not detected a dramatic protein-induced bend in the Ets-1-binding site by gel mobility-shift 
assays with permuted binding site probes (J. Petersen and C. Hull, unpubl.|. However, slight differences in the mobility of protein-DNA complexes in these assays are consistent with a subtle conformational change.

\section{Unique mode of binding for ETS domain family}

Chemical mapping studies have been performed on proteins that represent many of the structural motifs for sequence-specific DNA binding. In several cases, crystallographic studies have confirmed the features of DNAprotein interactions defined by chemical approaches $[\lambda$ repressor (Jordan and Pabo 1988); EcoRI (McClarin et al. 1986); MAT $\alpha 2$ (Wolberger et al. 1991). Members of a family of DNA-binding proteins that share a structural motif generally display a similar pattern of contacts. For a new family of DNA-binding proteins, such as the ETS domain group, these types of data can establish the uniqueness of the family and provide a means for identifying new members. The distinctive features of Ets-1 binding to DNA include interactions with four segments of the phosphodiester backbone, a central major groove contact zone of $5 \mathrm{bp}$, and two putative minor groove contact zones. Although detailed mapping studies have not been performed on other ETS domain proteins, the DNase I hypersensitive site (between positions 8 and 9 on the TCC strand) that we noted within a number of Ets-1 binding sites also is observed in footprint patterns of other members of the ets family (Urness and Thummel 1990). We speculate that all ETS domain proteins bind DNA in a similar manner.

To demonstrate the uniqueness of the ETS domain mode of binding, we briefly compare the contact pattern of Ets-1 to the patterns generated by four other structural motifs that bind DNA in the major groove. Contacts made by homeo domain proteins have been mapped by ethylation interference and hydroxyl radical protection (Sauer et al. 1988; Affolter et al. 1990). Contacts are made on three segments of the phosphodiester backbone, outlining the major groove and the contiguous minor groove on one face of the helix. The X-ray crystal structure of the engrailed and MAT $\alpha 2$ homeo domain bound to DNA shows the major groove filled by the helix-turnhelix motif and interactions of a flexible arm within the minor groove (Kissinger et al. 1990; Wolberger et al. 1991). The ethylation interference data for the helixturn-helix motif of $\lambda$ repressor illustrate the contact pattern of dimeric helix-turn-helix proteins. The phosphate contacts map to four segments of the phosphodiester backbone on one face of the helix (Johnson 1980), highlighting a central minor groove zone and two regions of major groove contact. Crystallographic studies demonstrate the presence of the two helix-turn-helix motifs within the major groove (Jordan and Pabo 1988). A different pattern of protection is caused by basic leucine zipper (bZIP) proteins. The major groove contact zone spans 12 contiguous nucleotides as evidenced by ethylation interference over this region on both strands (Nye and Graves 1990). There is only minor protection of the DNA helix from hydroxyl radical cleavage, suggesting no minor groove interactions (Vinson et al. 1989). The $\mathrm{C}_{6}$ zinc finger motif found in GAL4 and other related DNAbinding proteins has also been studied by chemical mapping techniques (Carey et al. 1989; Halvorsen et al. 1991). These proteins display a unique pattern of hydroxyl radical protection and ethylation interference along an extensive region in the center of the binding site. The pattern outlines a central minor groove contact region. Putative base contacts map to the major groove on both sides of this central zone.

These comparisons of ethylation interference and hydroxyl radical protection data demonstrate that the ETS domain of Ets-1 contacts DNA in a novel manner. The uniqueness of the contact pattern observed with Ets-1 is consistent with the distinctive character of the primary sequence of the ETS domain. None of the landmark features of the structural motifs described above have been noted in the ETS domain sequence (Karim et al. 1990). It is now clear from the binding site analysis that the ETS domain identifies a new family of DNA-binding proteins.

The ETS domain mode of DNA binding accommodates associated proteins

As described above, several ETS domain proteins bind DNA in association with other proteins. The ETS domain protein and the associated protein could bind the major groove on the same face of the DNA helix. We have detected this arrangement of binding sites in the enhancer of the murine leukemia virus (MLV) LTR. The major groove contacts of Ets-1 and the core-binding-protein CBF (Wang and Speck 1992), are positioned $10 \mathrm{bp}$ apart on the DNA helix, as determined by ethylation and methylation interference experiments (N.A. Speck and B.J. Graves, unpubl.).

A different configuration of neighboring binding sites appears to be represented by the binding of GABP. The two $\alpha$-subunits of GABP each contain an ETS domain. Thompson et al. (1991) proposed that GABP recognizes two GGA motifs that are separated by one-half turn of the DNA helix, ... GGANNNGGA .... This spacing places the major groove interactions of the two ETS domains on opposite faces of the DNA helix (front and back face in a planar helix; Fig. 91. This orientation could accommodate a 9-bp contact zone for each ETS domain, as only $5 \mathrm{bp}$ are proposed to be contacted in the major groove. The $3 \mathrm{bp}$ that lie between the two GGA motifs would be recognized in the minor groove by the first ETS domain and in the major groove by the second ETS domain. Phosphodiester backbone interactions spanning 20 bp were observed in the binding of Ets- 1 to the DNA helix. Even this large stretch of putative contacts could be accommodated by positioning GABP on two faces of the helix.

Sequence specificity of DNA binding of the ETS domain proteins

All ets family members bind sites containing a central 
GGA triplet. The flanking sequences may mediate the specificity of binding of different ETS domain proteins. For example, a set of sequences could be uniquely preferred by Ets-1 and not tolerated in sites bound by other family members. Sites recognized by other ets family members are listed in Figure 3. The selected consensus for Ets-1 shows a preference for RCC to the left of the GGA triplet. This sequence pattern is not present in the binding sites of other family members. Figure $10 \mathrm{com}$ pares the Ets- 1 consensus to the consensus binding site of Drosophila E74A (Urness and Thummel 1990). The consensus binding sites of E74A and Ets- 1 are the same at positions $8-12$ and position 14 . However, the E74A consensus displays a pyrimidine preference at position 7 on the GGA strand, a position at which Ets-1 shows a clear choice for a purine residue. Furthermore, the lack of restriction to an $\mathrm{A}$ at position 13 and to $\mathrm{A}$ at position 15 is also distinct for the Ets- 1 consensus. These results suggest that the ETS domain mediates specificity of action of ets family members. On the basis of our results, the discriminating positions, 7,13 , and 15 , are in the proposed minor groove contact zone. Selection of consensus sites for other ETS domain proteins will be necessary to identify additional discriminating positions and determine whether they also map to proposed minor groove interactions.

\section{Materials and methods}

\section{Construction of bacterial expression plasmids}

The ets-1 cDNA was constructed from two mouse thymus cDNA clones (Gunther et al. 1990). The cDNA sequences of one clone, including $509 \mathrm{bp}$ of the untranslated leader (5' UTR) and $690 \mathrm{bp}$ of amino-terminal coding sequences, were ligated at a native $\mathrm{HpaI}$ site to $63 \mathrm{l} \mathrm{bp}$ of carboxy-terminal coding sequences

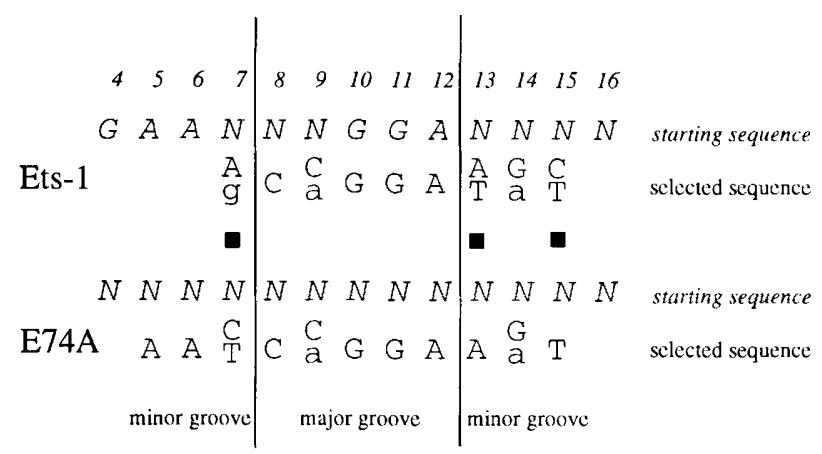

Figure 10. Comparison of the selected consensuses for two ETS domain proteins. Ets-1 data from Figs. 7 and 8. E74A data from a selection procedure that began with $25 \mathrm{bp}$ of random sequence (Urness and Thummel 1990). Two cycles of selection were performed by E74A affinity chromatography. DNA molecules that bound tightly were selected for cloning and sequencing. The consensus was derived from a statistical analysis of the sequences of 34 clones. ( $\square$ ) The positions of differences between the two consensuses. Vertical lines and minor groove and major groove labels designate proposed mode of recognition of DNA by ETS domain proteins. and $13 \mathrm{bp}$ of 3 ' UTR of a second clone. Initially, the entire 1849 bp were cloned into the BamHI site of pET3 vector (which contains 11 codons of T7 gene 10). To mediate expression of only Ets- 1 codons, the gene 10 codons, the 5' UTR and Ets-l codons 1-3 were removed by restriction with NdeI and EagI and replaced with an NdeI-EagI adapter $\left(5^{\prime}\right.$-TATGAAGGC-3'; $5^{\prime}$ GGCCGCCTTCA $\left.-3^{\prime}\right)$. This synthetic DNA contained a methionine codon in the context of an NdeI site and the first three Ets-l codons.

The pET3 vector system (Studier et al. 1990) also was used to express the mutant ets-1 polypeptides in Escherichia coli. In this case, the vectors retained 11 codons of the Slo gene (to provide a start codon), as well as the ets- 1 stop codon and $59 \mathrm{bp}$ of $3^{\prime}$ UTR. The polypeptide $\Delta \mathrm{N} 170$ was expressed from pETEts-1 (Gunther et al. 1990). For production of $\Delta N 322, \Delta N 326$, and $\Delta N 345$, the cDNA expressing $\Delta N 170$ was deleted by exonuclease III-SI nuclease treatment. A synthetic BamHI linker was ligated to the deleted cDNAs for cloning into pET3. Deletion end points were determined by dideoxy sequencing. Designating the start codon as the origin, the exact deletion end points for expression of $\Delta \mathrm{N} 170, \Delta \mathrm{N} 322, \Delta \mathrm{N} 336, \Delta \mathrm{N} 345$ were nucleotides $508,963,1006$, and 1033, respectively.

\section{Expression and partial purification of Ets-1 polypeptides}

For expression, pET plasmids were transformed into $E$. coli strain BL21 (DE3) containing the pLysS plasmid (Studier et al. 1990). Expression of foreign proteins was induced with $1 \mathrm{mM}$ IPTG for $1-2 \mathrm{hr}$ at $37^{\circ} \mathrm{C}$ (OD ${ }_{600}=0.7-0.9$ ). Expressed proteins were partially purified by the method of Landschulz et al. (1989). In brief, bacterial pellets from $50-\mathrm{ml}$ cultures were resuspended in $2 \mathrm{ml}$ of lysis buffer [5 $\mathrm{M}$ urea, $10 \mathrm{~mm}$ Tris- $\mathrm{Cl}(\mathrm{pH}$ 7.9), $0.15 \mathrm{M} \mathrm{NaCl}$, and $0.1 \%$ Triton X-100|. Cells were sonicated discontinuously for $1 \mathrm{~min}$ at $30 \mathrm{~W}$. Samples were centrifuged at $10,000 \mathrm{~g}$ for $5 \mathrm{~min}$ at $4^{\circ} \mathrm{C}$. Soluble proteins were applied to a DEAE-cellulose column equilibrated in urea-lysis buffer without the Triton X-100. Unbound proteins were dialyzed against TGMEK $_{100}$ [25 mM Tris-Cl (pH 7.9), 10\% glycerol, 5 mM $\mathrm{MgCl}_{2}$, $1 \mathrm{mM}$ EDTA, $100 \mathrm{~mm} \mathrm{KCl}, 0.1 \mathrm{~mm}$ PMSF, $1 \mathrm{~mm}$ dithiothreitol (DTT)]. After dialysis, samples were centrifuged at $10,000 \mathrm{~g}$ for $30 \mathrm{~min}$, and the supernatant was frozen in liquid nitrogen and stored at $-80^{\circ} \mathrm{C}$.

For large-scale purification of $\Delta \mathrm{N} 322$, a bacterial pellet from a $125-\mathrm{ml}$ culture was resuspended in $10 \mathrm{ml}$ of lysis buffer $[50 \mathrm{mM}$ Tris-Cl (pH 8.0), $0.2 \mathrm{M} \mathrm{NaCl}, 0.1 \mathrm{~mm}$ PMSF, $1 \mathrm{mM} \mathrm{DTT}, 1 \mu \mathrm{g} / \mathrm{ml}$ of leupepsin]. Cells were sonicated discontinuously for $3 \mathrm{~min}$ on ice. The sample was then centrifuged for $20 \mathrm{~min}$ at $27,000 \mathrm{~g}$. Soluble proteins were precipitated by adding 0.5 grams of $\left(\mathrm{NH}_{4}\right)_{2} \mathrm{SO}_{4} / \mathrm{ml}$ of extract and gentle stirring for $1 \mathrm{hr}$. The precipitate was collected by centrifugation for $15 \mathrm{~min}$ at $27,000 \mathrm{~g}$. The pellet was resuspended in chromatography buffer, TGEK $_{100}$ [10 mM Tris-Cl (pH 7.9), 10\% glycerol, 0.1 mM EDTA, and 100 $\mathrm{mM} \mathrm{KCl}$ ] and dialyzed against the same buffer. The sample was cleared by centrifugation at $48,000 \mathrm{~g}$ for $30 \mathrm{~min}$ and applied to a 5-ml DEAE-cellulose column (equilibrated with TGEK $_{100}$ ). Unbound protein was then applied to a $1-\mathrm{ml}$ Mono-S column (Pharmacia). Bound protein was eluted in a $20-\mathrm{ml}$ linear gradient from 100 to $350 \mathrm{~mm} \mathrm{KCl}$. Fractions containing DNA-binding activity eluted between 200 and $250 \mathrm{~mm} \mathrm{KCl}$. Active fractions were frozen in liquid nitrogen and stored at $-80^{\circ} \mathrm{C}$. In peak fractions, $\Delta N 322$ was $80-90 \%$ pure as estimated by Coomassie blue staining of an SDS-PAGE gel. The extinction coefficient of the $\Delta \mathrm{N} 322$ was estimated by the method of Gill and von Hippel (1989) to be $26,152 \mathrm{M}^{-1} \mathrm{~cm}^{-1}$ at $278 \mathrm{~nm}$. We used this value to interpret optical density measurements and estimate the 
$\Delta \mathrm{N} 322$ concentration in stock solutions. Estimated yield from the 125 -ml culture was $0.85 \mathrm{mg}$.

For further purification of Ets-1, a bacterial pellet from $100-\mathrm{ml}$ culture was subjected to the urea-lysis protocol described above except for the following modifications. The scale of the lysis step and DEAE-chromatography was increased twofold and the dialysis was against TGEK $_{100}$. Cleared sample was applied to a 1.0-ml Mono-S column (Pharmacia) (equilibrated in $\mathrm{TGEK}_{100}$ ). Bound protein was eluted with a $20-\mathrm{ml}$ linear gradient from 0.1 to $1 \mathrm{M} \mathrm{KCl}$. Ets-1 eluted in fractions containing $150-200 \mathrm{mM}$ $\mathrm{KCl}$. Ets-1 was estimated to be $95 \%$ pure based on Coomassie blue staining of a SDS-PAGE gel. Protein concentration was estimated as described above for $\Delta \mathrm{N} 322$, based on an extinction coefficient of $87,470 \mathrm{M} / \mathrm{cm}$.

\section{DNA-binding site probes}

Probes were labeled on $5^{\prime}$-extended ends with $\left[\gamma^{-}{ }^{32} \mathrm{P}\right] \mathrm{ATP}$ and T4 polynucleotide kinase (New England Biolabs) after treatment with calf intestinal phosphatase (Sigma). The 3 '-recessed ends were labeled by fill-in with an appropriate $\left[\alpha-{ }^{32} \mathrm{P}\right] \mathrm{dNTP}$ and E. coli DNA polymerase, Klenow fragment (New England Biolabs). Probes were resolved on $4-6 \%$ acrylamide $/ 0.25 \%$ agarose gels and electroeluted onto NA-45 paper (Schleicher \& Schuell) in Western blot buffer (12.5 mM Tris-Cl, $96 \mathrm{~mm}$ glycine). The paper was then incubated in $1 \mathrm{M} \mathrm{NaCl} / 0.05 \mathrm{M}$ arginine at $65^{\circ} \mathrm{C}$ for $2 \mathrm{hr}$. The DNA solution was diluted $1: 1$ with TE $[10 \mathrm{mM}$ Tris-Cl (pH 8.0), 1 mM EDTA], and DNA was ethanol precipitated.

The MSV LTR enhancer site probe was prepared from a plasmid bearing the LTR sequences between viral genome positions 201 and 221 (Van Beveren et al. 1981). This plasmid was constructed by synthesizing the complementary oligonucleotides 5'-GATCTGCTTACCACAGATATCCTGTTTGG-3' and $5^{\prime}$ GATCCCAAACAGGATATCTGTGGTAAGCA-3'. The oligonucleotides were annealed and cloned into the BamHI site of pKS (Stratagene). Probe DNA for the enhancer site was a 95-bp HindIII/SacI fragment. The MSV LTR promoter site probe was prepared from peMSV $(-74 /-31)$ bearing the MSV LTR sequences from 372 to 413 (Gunther et al. 1990). Probe DNA for the promoter site was an $85-\mathrm{bp}$ EcoRI/HindIII restriction fragment. The SC site probes used in the protection assays were restricted with EagI and $\mathrm{KpnI}$ to generate an 81-bp fragment. In all other assays, the $\mathrm{SC}$ site probes were prepared as 6l-bp, $X$ baI-ApaI restriction fragments.

\section{Protein-DNA-binding reactions and gel mobility-shift assays}

DNA-binding reactions for gel mobility-shift assays contained radiolabeled probes (6-10 fmoles, unless otherwise noted) and protein preparations in a final volume of $20 \mu \mathrm{l}$ of binding buffer [ $65 \mathrm{~mm} \mathrm{KCl}, 25 \mathrm{~mm}$ Tris-Cl (pH 7.9), $6 \mathrm{~mm} \mathrm{MgCl}_{2}, 0.25-0.5 \mathrm{~mm}$ EDTA, $10 \%$ glycerol]. Bovine serum albumin was included $(0.15-0.2 \mathrm{mg} / \mathrm{ml})$ in all reactions. Poly[d(I-C)] was included as a nonspecific competitor as needed. After incubation on ice for 20 min, DNA-protein complexes were resolved on $5 \%$ polyacrylamide gels [acrylamide/bis, $30: 0.8 ; 45 \mathrm{~mm}$ Tris-borate $(\mathrm{pH}$. 8.31, $1 \mathrm{~mm}$ EDTA] at $4^{\circ} \mathrm{C}$. Gels were prerun for $1 \mathrm{hr}$ at constant voltage of $17 \mathrm{~V} / \mathrm{cm}$. The samples were loaded with voltage set at $7.7 \mathrm{~V} / \mathrm{cm}$ and resolved by electrophoresis for $2-3 \mathrm{hr}$ at $17 \mathrm{~V} / \mathrm{cm}$.

\section{DNase I and hydroxyl radical protection assays}

The hydroxyl radical protection assays were performed as de scribed previously (Tullius et al. 1987), with the following modifications. Binding reactions with a final volume of $35 \mu \mathrm{l}$ were prepared as described above except that the glycerol level was reduced to $<0.5 \%$. The cutting reaction was initiated by the addition of $15 \mu \mathrm{l}$ of premixed reagents. The final concentrations of $\mathrm{H}_{2} \mathrm{O}_{2}$, sodium ascorbate, iron (II), and EDTA in the binding reaction were $0.01 \%, 3 \mathrm{mM}, 0.3 \mathrm{mM}$, and $0.6 \mathrm{mM}$, respectively. Cutting was stopped after $5 \mathrm{~min}$ at $20^{\circ} \mathrm{C}$ by the addition of $21 \mu \mathrm{l}$ of stop solution [0.1 $\mathrm{M}$ thiourea, $0.2 \mathrm{M}$ EDTA]. DNase I protection assays were performed as described previously /Graves et al. 1986). Cleavage products from both hydroxyl radical and DNase I protection assays were resolved on $9 \%$ sequencing gels. Autoradiographs were obtained by exposure to X-ray film with the aid of an intensifying screen. Autoradiographs were scanned with a Bio-Rad densitometer, and film densities were plotted with 1-D Analyst Macintosh (Bio-Rad) software. Quantitative analyses were performed using peak heights of absorbance as an estimate of band density.

\section{Alkylation interference assays}

Alkylation interference assays were performed as described previously (Nye and Graves 1990). End-labeled DNA (0.3-0.5 pmole of radiolabeled probe and $2.5 \mu \mathrm{g}$ of poly[d(I-C)] was methylated with dimethyl sulfate (Aldrich) (Maxam and Gilbert 1980) or ethylated with ENU (Sigma) (Siebenlist and Gilbert 1980). To ethylate probe, DNA was incubated in $40 \mu \mathrm{l}$ of $0.3 \mathrm{M}$ sodium cacodylate ( $\mathrm{pH} 7.3$ ) and $40 \mu$ l of ethanol saturated with ENU $\{0.3$ grams of ENU $/ \mathrm{ml}$ of $95 \%$ ethanol) for $20 \mathrm{~min}$ at $50^{\circ} \mathrm{C}$. The reaction was stopped by ethanol precipitation with ammonium acetate and incubation at $-70^{\circ} \mathrm{C}$. Binding reactions performed in buffer conditions described above contained 35 105 fmoles of modified DNA and sufficient protein to achieve a $10-30 \%$ shift of the probe. Bound and unbound DNA fractions were recovered by electroelution as described above, with the addition of $5 \mu \mathrm{g}$ of tRNA as carrier in the ethanol precipitation. Phosphotriester bonds were cleaved by resuspension of DNA in 10 mM sodium phosphate ( $\mathrm{pH} 7.0$ ), 1 mM EDTA, followed by the addition of an equal volume of $0.3 \mathrm{M} \mathrm{NaOH}$ and a 30 -min incubation at $90^{\circ} \mathrm{C}$. DNA was cleaved at methylated guanine residues by incubation in $1 \mathrm{M}$ piperidine for $30 \mathrm{~min}$ at $90^{\circ} \mathrm{C}$ (Maxam and Gilbert 1980). Cleavage at methylated adenines occurred during the NA45 paper elution procedure. Modified control DNA was not electrophoresed prior to strand cleavage. Equal amounts of radioactivity from bound, unbound, and control samples were resolved on sequencing gels. Gels were exposed to film, and autoradiographic densities were quantified as described above. Value ranges for each interfering site were observed in at least two independent experiments.

\section{Selected and amplified binding assays}

The selection and amplification of Ets-1-binding sites were performed with the following oligonucleotides: template N1, 5'CTCGAGTAGCATGCACANNNNTCCNNNTTGGCCGTCGACTAGATCT-3'; primer A, 5'-GCGAGATCTAGTCGACGG-3'; primer B, 5'-GCGCTCGAGTAGCATGCA-3'. The central 20 nucleotides of N1 DNA represented MSV LTR enhancer sequences on the noncoding viral strand between viral genome positions 200 and 221 (Van Beveren et al. 1981) except for the 7 positions with random sequence. The flanking regions of $\mathrm{Nl}$ contained restriction enzyme recognition sequences $\mathrm{XhoI}$ plus SphI within the left 13 nucleotides and SalI plus BglII within the right 13 nucleotides. Primer A was complementary to the $3^{\prime}$ end of the N1 plus a 3-nucleotide 5 ' extension. Primer $\mathrm{B}$ was identical to the $5^{\prime}$ end of Nl with a 3-nucleotide $5^{\prime}$ extension. Each oligonucleotide was synthesized, and full-length products were resolved from shorter products by gel purifica- 
tion. Double-stranded DNA for binding reactions was generated by annealing primer $A$ in a fivefold molar excess to N1, synthesizing the complementary strand with E. coli DNA polymerase (Klenow fragment) and isolating the product on a $6 \%$ acrylamide $/ 0.25 \%$ agarose gel. DNA was electroeluted, radiolabeled with $\left[\gamma^{-}{ }^{32} \mathrm{P}\right] \mathrm{ATP}$ and T4 polynucleotide kinase, and applied to a Bio-Rad spin 6 column to separate from nucleotides.

DNA-binding reactions and mobility-shift assays were performed as described above. Each contained $1.0 \mathrm{ng}$ of probe $\left(1.45 \times 10^{-9} \mathrm{M}\right)$ and $0.36 \mathrm{ng}$ of highly-purified $\Delta \mathrm{N} 322$ $\left(1.3 \times 10^{-9} \mathrm{M}\right)$. The wet gel was exposed to X-ray film for $8-20$ hr at $4^{\circ} \mathrm{C}$. DNA in complex with a monomeric protein species was gel purified by electroelution with $5 \mu \mathrm{g}$ of tRNA in the final ethanol precipitation step. In the first round, the radioactivity of the DNA-protein complex was not detectable on X-ray film. To locate the position of nucleoprotein complexes, a binding reaction was electrophoresed in parallel that contained a 1000-fold higher concentration of $\Delta \mathrm{N} 322$. A ladder of complexes was observed in this marker lane. The fastest complex provided a marker for the mobility of a monomeric complex. In subsequent rounds, a radioactive signal was visible at this position.

One-fifth of the gel-purified DNA was used in a PCR reaction at a final buffer concentration of $10 \mathrm{~mm}$ Tris- $\mathrm{Cl}$ (pH 8.4), $50 \mathrm{~mm}$ $\mathrm{KCl}, 1.5 \mathrm{mM} \mathrm{MgCl}_{2}, 100 \mu \mathrm{g} / \mathrm{ml}$ of gelatin, $200 \mu \mathrm{M}$ each $\mathrm{dNTP}$, $2.5 \mu \mathrm{M}$ each primer (A and B), and 2.5 units of Taq polymerase (Perkin Elmer). Reactions were incubated at $95^{\circ} \mathrm{C}(20 \mathrm{sec}), 55^{\circ} \mathrm{C}$ (30 sec), $72^{\circ} \mathrm{C}(20 \mathrm{sec})$ for 35 cycles, and $72^{\circ} \mathrm{C}(3 \mathrm{~min})$. The reaction was extracted with an equal volume of chloroform, and the PCR product was resolved on a $6 \%$ polyacrylamide $/ 0.25 \%$ agarose gel and recovered by electroelution. Labeling of the DNA and mobility-shift assays was performed in an identical manner for each of four subsequent selection rounds. The sixth round of selection was performed under more stringent binding reaction conditions $\left(1.45 \times 10^{-10} \mathrm{M} \Delta \mathrm{N} 322\right)$. After each round of selection, approximately one-tenth of the PCR product was sequenced directly by dideoxy sequencing with Sequenase and U.S. Biochemical sequencing kits. Radiolabeled primer A or B was added in a fivefold molar excess to template DNA 10.35 pmole template was annealed to 2.1-pmole primer in $12-\mu \mathrm{l}$ reaction/ and sequenced according to Blackwell and Weintraub (1990). The starting DNA was subjected to PCR amplification before sequencing.

A portion of the PCR product obtained after the fifth round of selection was cloned into the polylinker of the Bluescript vector pKS (Stratagene) between the BglII and XhoI site by standard cloning procedures. To obtain sufficient quantities of DNA for cloning, the round 5 product was reamplified. Inserts were sequenced by dideoxy sequencing using Sequenase (U.S. Biochemical).

\section{Determination of SC binding-site affinities}

The binding affinities of $14 \mathrm{SC}$ binding sites were determined relative to the affinity of $\mathrm{SC} 2$ by competition experiments. To determine the affinity of the $\mathrm{SC} 2$ binding site, quantitative mobility-shift assays were performed on the SC2 probe under conditions in which the amount of protein was constant and the amount of probe DNA was varied (DNA titrations). The amount of unbound and bound probe was measured by phosphorimaging (Molecular Dynamics). The data were plotted by the method of Scatchard (ratio of bound and unbound vs. bound). The linear correlation of the two variables provided an estimate of the dissociation constant, $K_{\mathrm{d}}=-1 /$ slope. The $x$-intercept estimated the concentration of protein active in binding. This value correlated closely with the concentration of $\Delta \mathrm{N} 322$ estimated by spectrophotometric measurements. The affinity of the SC2- binding site for $\Delta \mathrm{N} 322$ was determined independently by quantitative protein titrations (Brenowitz et al. 1986). The value obtained $\left(K_{\mathrm{d}}=2.8 \times 10^{-11} \mathrm{M}\right)$ was close to the value obtained by the DNA titration experiment $\left(K_{\mathrm{d}}=4.9 \times 10^{-11}\right)$. The DNA titration design and Scatchard analysis allowed us to measure the values for total protein concentration, $P_{\mathrm{t}}$, and $K_{\mathrm{d}}$ for SC2 on the same mobility-shift gel using the same protein sample and radiolabeled probe that was used in the following competition experiments. Therefore, we used the $K_{\mathrm{d}}=4.9 \times 10^{-11}$ value in calculation of relative affinities.

Competitions were performed with a constant amount of radiolabeled SC2 DNA $\left(1.24 \times 10^{-} 10 \mathrm{M}\right)$ and $\Delta \mathrm{N} 322\left(1.37 \times 10^{-9}\right.$ M). Competitor DNA ranged between 2 and $6 \mathrm{ng}$. To obtain competitor DNA, 1-2 $\mu \mathrm{g}$ of 61-bp XbaI-ApaI restriction fragments for each SC site were gel purified. Aliquots of the stock solutions were electrophoresed in parallel with DNA standards whose concentrations were determined spectrophotometrically. The DNA concentration of a stock competitor solution was determined by video densitometry performed on photographic negatives of ethidium-stained $6 \%$ polyacrylamide/ $0.25 \%$ agarose gels.

The strategy for our quantitative analysis assumed that a coupled equilibrium exists between added $\Delta N 322$ and the two binding sites (Liu-Johnson et al. 1986; Li et al. 1989). To calculate the dissociation equilibrium constant for a SC-binding site, $X$, $\mid K_{\mathrm{d}}{ }^{\mathrm{x}}=[\mathrm{P}]\left[\mathrm{D}^{\mathrm{x}}\right] /\left[\mathrm{PD}^{\mathrm{x}}\right]$, reactant and product concentrations were derived from the following measurable parameters: $P_{t}$ the total added protein; $D_{\mathrm{t}}^{\mathrm{x}}$, total added competitor site; $K_{\mathrm{d}}^{\mathrm{SC} 2}$, dissociation constant for $\mathrm{SC2}$-binding site; $\left[\mathrm{PD}^{\mathrm{SC} 2}\right], \mathrm{SC} 2 \mathrm{DNA}$ in complex; $\left[D^{\mathrm{SC}}\right]$, unbound SC2 DNA. The latter two values were obtained from phosphorimaging analysis of the mobility-shift gels to determine the fraction of the total added SC2 site DNA in bound and unbound fractions. With these values, we calculated as follows: $[\mathrm{P}]=\left[\mathrm{PD}^{\mathrm{SC} 2}\right] K_{\mathrm{d}}^{\mathrm{SC} 2} /\left[\mathrm{D}^{\mathrm{SC} 2}\right] ; \quad\left[\mathrm{PD}^{\mathrm{x}}\right]=P_{\mathrm{t}} \cdot[\mathrm{P}]$ $-\left[\mathrm{PD}^{\mathrm{SC} 2}\right] ;\left[\mathrm{D}^{\mathrm{x}}\right]=D_{\mathrm{t}}^{\mathrm{x}}-\left[\mathrm{PD}^{\mathrm{x}}\right]$ and thus $K_{\mathrm{d}}^{\mathrm{x}}$.

The GenBank accession number for murine ets-1 cDNA is X53953.

\section{Acknowledgments}

We thank Diane Richardson for assistance in protein preparation. We thank Tom Alber and Brenda Bass for critical comments on the manuscript. This work was supported by National Institutes of Health (NIH) grant GM38663 and the March of Dimes Birth Defects Foundation Basic Research grant 1-0138 awarded to B.J.G. C.G. was funded as a predoctoral trainee on the NIH Cancer Training Grant CA09602.

The publication costs of this article were defrayed in part by payment of page charges. This article must therefore be hereby marked "advertisement" in accordance with 18 USC section 1734 solely to indicate this fact.

\section{References}

Affolter, M., A. Percival-Smith, M. Müller, W. Leupin, and W.J. Gehring. 1990. DNA binding properties of the purified Antennapedia homeodomain. Proc. Natl. Acad. Sci. 87: 40934097.

Ben-David, Y., E.B. Giddens, K. Letwin, and A. Bernstein. 1991. Erythroleukemia induction by Friend murine leukemia virus: Insertional activation of a new member of the ets gene family, Fli-1, closely linked to c-ets-1. Genes \& Dev. 5: 908918.

Blackwell, T.K. and H. Weintraub. 1990. Differences and similarities in DNA-binding preferences of MyoD and E2A pro- 
tein complexes revealed by binding site selection. Science 250: 1104-1110.

Bosselut, R., J.F. Duvall, A. Gegonne, M. Bailly, A. Hemar, J. Brady, and J. Ghysdael. 1990. The product of the c-ets-1 proto-oncogene and the related Ets2 protein act as transcriptional activators of the long terminal repeat of human $\mathrm{T}$ cell leukemia virus HTLV-1. EMBO I. 9: 3137-3144.

Brenowitz, M., D.F. Senear, M.A. Shea, and G.K. Ackers. 1986. Quantitative DNase footprint titration: A method for studying protein-DNA interactions. Methods Enzymol. 130: 132181.

Burtis, K.C., C.S. Thummel, C.W. Jones, F.D. Karim, and D.S. Hogness. 1990. The Drosophila 74EF early puff contains E74, a complex ecdysone-inducible gene that encodes two etsrelated proteins. Cell 61: 85-99.

Calladine, C.R. 1982. Mechanics of sequence-dependent stacking of bases in B-DNA. J. Mol. Biol. 161: 343-352.

Carey, M., H. Kakidani, J. Leatherwood, F. Mostashari, and M. Ptashne. 1989. An amino-terminal fragment of GAL4 binds DNA as a dimer. J. Mol. Biol. 209: 423-432.

Dalton, S. and R. Treisman. 1992. Characterization of SAP-1, a protein recruited by serum response factor to the c-fos serum response element. Cell 68: 597-612.

Fisher, R.J., G. Mavrothalassitis, A. Kondoh, and T.S. Papas. 1991. High-affinity DNA-protein interactions of the cellular ETS1 protein: The determination of the ETS binding motif. Oncogene 6: 2249-2254.

Gill, S.C. and P.H. von Hippel. 1989. Calculation of protein extinction coefficients from amino acid sequence data. Anal. Biochem. 182: 319-326.

Graves, B.J., P.F. Johnson, and S.L. McKnight. 1986. Homologous recognition of a promoter domain common to the MSV LTR and the HSV tk gene. Cell 44: 565-576.

Gunther, C.V., J.A. Nye, R.S. Bryner, and B.J. Graves. 1990. Sequence-specific DNA binding of the proto-oncoprotein Ets-1 defines a transcriptional activator sequence within the long terminal repeat of the Moloney murine sarcoma virus. Genes \& Dev. 4: 667-679.

Halvorsen, Y.-D.C., K. Nandabalan, and R.C. Dickson. 1991. Identification of base and backbone contacts used for DNA sequence recognition and high-affinity binding by LAC9, a transcription activator containing a $\mathrm{C} 6$ zinc finger. Mol. Cell. Biol. 11: 1777-1784.

Harrison, S.C. 1991. A structural taxonomy of DNA-binding domains. Nature 353: 715-719.

Hipskind, R.A., V.N. Rao, C.G.F. Mueller, E.S.P. Reddy, and A. Nordheim. 1991. Ets-related protein Elk-1 is homologous to the c-fos regulatory factor $\mathrm{p} 62^{\mathrm{TCF}}$. Nature 354: 531-534.

Ho, I.-C., N.K. Bhat, L.R. Gottschalk, T. Lindsten, C.B. Thompson, T.S. Papas, and J.M. Leiden. 1990. Sequence-specific binding of human Ets- 1 to the $T$ cell receptor $\alpha$ gene enhancer. Science 250: 814-818.

Johnson, A. 1980. "Mechanism of action of the Cro protein." Ph.D. thesis, Harvard University, Cambridge, MA.

Johnson, P.F. and S.L. McKnight. 1989. Eukaryotic transcriptional regulatory proteins. Annu. Rev. Biochem. 58: 799839.

Jordan, S.R. and C.O. Pabo. 1988. Structure of the lambda complex at $2.5 \AA$ resolution: Details of the repressor-operator interactions. Science 242: 893-899.

Karim, F.D., L.D. Urness, C.S. Thummel, M.J. Klemsz, S.R. McKercher, A. Celeda, C. Van Beveren, R.A. Maki, C.V. Gunther, J.A. Nye, and B.J. Graves. 1990. The ETS-domain: A new DNA binding motif that recognizes a purine-rich core DNA sequence. Genes \& Dev. 4: 1451-1453.

Kissinger, C.R., B. Liu, E. Martin-Blanco, T.B. Kornberg, and
C.O. Pabo. 1990. Crystal structure of an engrailed homeodomain-DNA complex at $2.8 \AA$ resolution: A framework for understanding homeodomain-DNA interactions. Cell 63: $579-590$.

Klemsz, M.J., S.R. McKercher, A. Celada, C. Van Beveren, and R.A. Maki. 1990. The macrophage and B cell specific transcription factor PU.1 is related to the ets oncogene. Cell 61: 113-124.

LaMarco, K., C.C. Thompson, B.P. Byers, E.M. Walton, and S.L. McKnight. 1991. Identification of ets- and notch-related subunits in GA binding protein. Science 253: 789-792.

Landschulz, W.H., P.F. Johnson, and S.L. McKnight. 1989. The DNA binding domain of the rat liver nuclear protein C/EBP is bipartite. Science 243: 1681-1688.

Leprince, D., A. Gegonne, J. Coll, C. de Taisne, A. Schneeberger C. Lagrou, and D. Stehelin. 1983. A putative second cellderived oncogene of the avian leukaemia retrovirus E26. $\mathrm{Na}$ ture 306: 395-397.

Li, R., J. Knight, G. Bream, A. Stenlund, and M. Botchan. 1989. Specific recognition nucleotides and their DNA context determine the affinity of E2 protein for 17 binding sites in the BPV-1 genome. Genes \& Dev. 3: 510-526.

Lim, F., N. Kraut, J. Frampton, and T. Graf. 1992. DNA binding by c-Ets-1, but not v-Ets, is repressed by an intramolecular mechanism. EMBO /. 11: 643-652.

Liu-Johnson, H., M. Gartenberg, and D. Crothers. 1986. The DNA binding domain and bending angle of E. coli CAP protein. Cell 47: 995-1005.

Maxam, A. and W. Gilbert. 1980. Sequencing end-labeled DNA with base specific chemical cleavages. Methods Enzymol. 65: 499-560.

McClarin, J.A., C.A. Frederick, B.-C. Wang, P. Greene, H.W. Boyer, J. Grable, and J.M. Rosenberg. 1986. Structure of the DNA-Eco RI endonuclease recognition complex at $3 \AA$ resolution. Science 234: 1526-1541.

Nye, J.A. and B.J. Graves. 1990. Alkylation interference identifies essential DNA contacts for sequence-specific binding of the eukaryotic transcription factor C/EBP. Proc. Natl. Acad. Sci. 87: 3992-3996.

Pongubala, J.M.R., S. Nagulapalli, M.J. Klemsz, S.R. McKercher, R.A. Maki, and M.L. Atchison. 1992. PU.1 recruits a second nuclear factor to a site important for immunoglobulin $\kappa 3^{\prime}$ enhancer activity. Mol. Cell. Biol. 12: 368-378.

Radke, K., H. Beug, S. Kornfeld, and T. Graf. 1982. Transformation of both erythroid and myeloid cells by E26, an avian leukemia virus that contains the myb gene. Cell 31: 643653.

Sauer, R.T., D.L. Smith, and A.D. Johnson. 1988. Flexibility of the yeast $\alpha 2$ repressor enables it to occupy the ends of its operator, leaving the center free. Genes \& Dev. 2: 807-816.

Seeman, N.C., J.M. Rosenberg, and A. Rich. 1976. Sequencespecific recognition of double helical nucleic acids by proteins. Proc. Natl. Acad. Sci. 73: 804-808.

Siebenlist, U. and W. Gilbert. 1980. Contacts between Escherichia coli RNA polymerase and an early promoter of phage T7. Proc. Nat1. Acad. Sci. 77: 122-126.

Steitz, T.A. 1990. Structure studies of protein-nucleic acid interaction: The sources of sequence-specific binding. Quarterly Rev. Biophys. 23: 205-280.

Studier, F.W., A.H. Rosenberg, J.J. Dunn, and J.W. Dubendorff. 1990. Use of T7 RNA polymerase to direct expression of cloned genes. Methods Enzymol. 185: 60-89.

Thompson, C.C., T.A. Brown, and S.L. McKnight. 1991. Convergence of Ets- and notch-related structural motifs in a heteromeric DNA binding complex. Science 253: 762-768.

Thompson, C.B., C. Wang, I.-C. Ho, P.R. Bohjanen, B. Petryniak, 
Nye et al.

C.H. June, S. Meisfeldt, L. Zhang, G.J. Nabel, B. Karpinski, and J.M. Leiden. 1992. cis-acting sequences required for inducible Interleukin-2 enhancer function bind a novel etsrelated protein, Elf-1. Mol. Cell. Biol. 12: 1043-1053.

Tullius, T.D., B.A. Dombroski, M.E.A. Churchill, and L. Kam. 1987. Hydroxyl radical footprinting: A high-resolution method for mapping protein-DNA contacts. Methods Enzymol. 155: 537-558.

Urness, L.D. and C.S. Thummel. 1990. Molecular interactions within the ecdysone regulatory hierarchy: DNA binding properties of the Drosophila ecdysone-inducible E74A protein. Cell 63: 47-61.

Van Beveren, C., F. van Straaten, J.A. Galleshaw, and I.M. Verma. 1981. Nucleotide sequence of the genome of a murine sarcoma virus. Cell 27: 97-108.

Vinson, C.R., P.B. Sigler, and S.L. McKnight. 1989. Scissors-grip model for DNA recognition by a family of leucine zipper proteins. Science 246: 911-916.

Wang, S. and N.A. Speck. 1992. Purification of core-binding factor, a binding that binds the conserved core site in murine leukemia virus enhancers. Mol. Cell. Biol. 12: 89-102.

Wasylyk, B., C. Wasylyk, P. Flores, A. Begue, D. Leprince, and D. Stehelin. 1990. The c-ets proto-oncogenes encode transcription factors that cooperate with c-Fos and c-Jun for transcriptional activation. Nature 346: 191-193.

Wasylyk, C., A. Gutman, R. Nicholson, and B. Wasylyk. 1991. The c-Ets oncoprotein activates the stromelysin promoter through the same elements as several non-nuclear oncoproteins. EMBO I. 10: 1127-1134.

Wolberger, C., A.K. Vershon, B. Liu, A.D. Johnson, and C.O. Pabo. 1991. Crystal structure of a MAT 2 homeodomainoperator complex suggests a general model for homeodomain-DNA interactions. Cell 67: 517-528.

Woods, D.B., J. Ghysdael, and M.J. Owen. 1992. Identification of nucleotide preferences in DNA sequence recognised specifically by c-Ets-1 protein. Nucleic Acids Res. 20: 699-704.

Xin, J., A. Cowie, P. Lachance, and J.A. Hassell. 1992. Molecular cloning and characterization of PEA3, a new member of the Ets oncogene family that is differentially expressed in mouse embryonic cells. Genes \& Dev. 6: 481-496. 


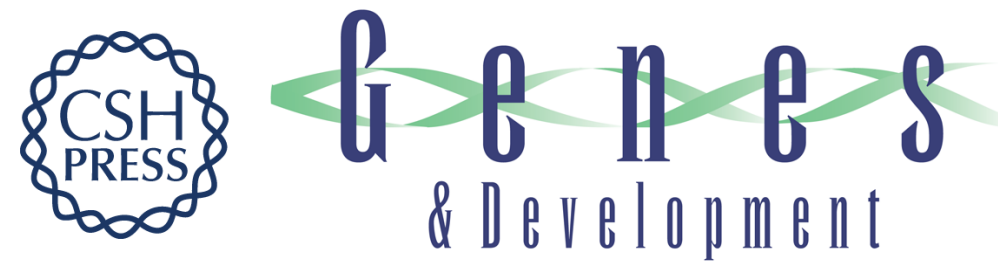

\section{Interaction of murine ets-1 with GGA-binding sites establishes the ETS domain as a new DNA-binding motif.}

J A Nye, J M Petersen, C V Gunther, et al.

Genes Dev. 1992, 6:

Access the most recent version at doi:10.1101/gad.6.6.975

References This article cites 50 articles, 22 of which can be accessed free at:

http://genesdev.cshlp.org/content/6/6/975.full.html\#ref-list-1

License

Email Alerting

Service

Receive free email alerts when new articles cite this article - sign up in the box at the top right corner of the article or click here.

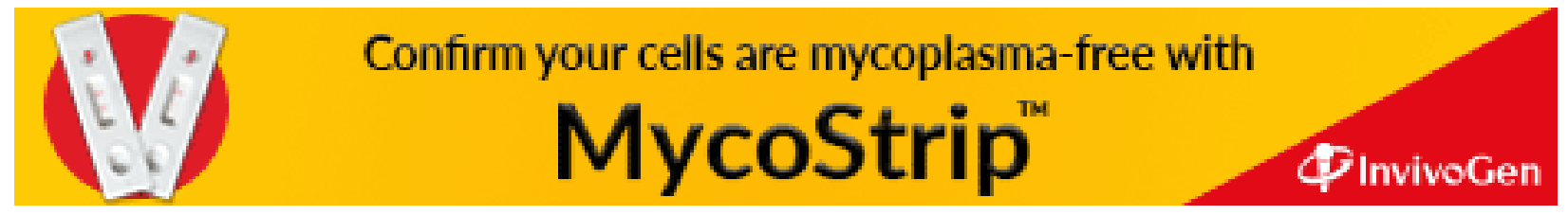

